DOE/ID/13555

Production and Machining of Thin Wall Gray and Ductile Cast Iron

Final Report - 07/01/1997 - 05/31/2000

H. Li

R. Griffin

C. E. Bates

E. Eleftheriou

November 2000

Work Performed Under Contract No. DE-FC07-97ID13555

For

U.S. Department of Energy

Assistant Secretary for

Energy Efficiency and Renewable Energy

Washington, DC

By

University of Alabama at Birmingham

Birmingham, AL 


\section{DISCLAIMER}

This report was prepared as an account of work sponsored by an agency of the United States Government. Neither the United States Government nor any agency thereof, nor any of their employees, make any warranty, express or implied, or assumes any legal liability or responsibility for the accuracy, completeness, or usefulness of any information, apparatus, product, or process disclosed, or represents that its use would not infringe privately owned rights. Reference herein to any specific commercial product, process, or service by trade name, trademark, manufacturer, or otherwise does not necessarily constitute or imply its endorsement, recommendation, or favoring by the United States Government or any agency thereof. The views and opinions of authors expressed herein do not necessarily state or reflect those of the United States Government or any agency thereof. 


\section{DISCLAIMER}

Portions of this document may be illegible in electronic image products. Images are produced from the best available original document. 


\title{
PRODUCTION AND MACHINING OF THIN WALL GRAY AND DUCTILE CAST IRON
}

\author{
FINAL REPORT \\ 07/01/1997 - 05/31/2000 \\ H. Li \\ R. Griffin \\ C. E. Bates \\ E. Eleftheriou
} BRTERYED

DEC 202000

\section{OSTI}

November 2000

Work Performed Under Contract No. DE-FC07-97ID13555

Prepared for the U.S. Department of Energy

Assistant Secretary for Energy Efficiency and Renewable Energy Washington, DC

Prepared by

University of Alabama at Birmingham

Birmingham, AL 
PRODUCTION AND MACHINING OF THIN WALL GRAY AND DUCTILE CAST IRON

\author{
Hanjun Li \\ Robin Griffin \\ Charles E. Bates \\ Evangelos Eleftheriou
}
Department of Materials \& Mechanical Engineering University of Alabama at Birmingham 917 Building, $15303^{\text {rd }}$ Avenue South Birmingham, Alabama 35294

November 3,2000

Prepared for the

U.S. Department of Energy

Idaho National Engineering Laboratory

Idaho Ealls, Idaho 83415

Under DOE Idaho Field Office

Contract DE-FC07-97ID13555 


\title{
PRODUCTION AND MACHINING OF THIN WALI GRAY AND DUCTILE CAST IRON
}

\author{
TABLE OF CONTENTS
}

ABSTRACT . . . . . . . . . . . . . . . . . . . . . . . vi

EXECUTIVE SUMMARY . . . . . . . . . . . . . . . . . . . . . . . 1

Gray Iron . . . . . . . . . . . . . . . . . . . . . . 1

Ductile Iron . . . . . . . . . . . . . . . . . . 2

INTRODUCTION . . . . . . . . . . . . . . . . . . . . . . . . 3

Metal Cutting Fundamentals . . . . . . . . . . . . . . 3

Cutting of Gray Irons . . . . . . . . . . . . . . . . . 3

Tool Failure Mechanisms . . . . . . . . . . . . . . 8

OBJECTIVES AND EXPERIMENTAL PROCEDURES . . . . . . . . . . . . . . 12

Casting Production and Effects
of Inoculation and Mold Material . . . . . . . . . . . . . 12

Effects of Composition and Section Size . . . . . . . . . . 16

Ductile Iron Casting Production . . . . . . . . . . . . . 17

Machinability Evaluation Procedures . . . . . . . . . . . . 17

Specimen Microscopy . . . . . . . . . . . . . . . . . . . 22

Casting Hardness . . . . . . . . . . . . . . . . . . 22

Brinell Hardness . . . . . . . . . . . . . . . 22

Matrix Mircohardness . . . . . . . . . . . . . 22

Ultrasonic Evaluation . . . . . . . . . . . . . . . 22

RESULTS AND DISCUSSION . . . . . . . . . . . . . . . . . . . . . . 24

Microstructural and Physical Property Analysis . . . . . . . 27

Analysis of Commercial Gray Iron Castings . . . . . . . . . . 33

Controlling Microcarbides . . . . . . . . . . . . . . . 40

Gray Iron Machinability Indicators . . . . . . . . . . . . . 41

Compressive Properties . . . . . . . . . . . . . 41

Ultrasonic Indicators . . . . . . . . . . . . . 42

Applications . . . . . . . . . . . . . . . . . . . . . 44

Machinability of Ductile Iron . . . . . . . . . . . . . 46

Conclusions . . . . . . . . . . . . . . . . . . 58

SUMMARY AND CONCLUSIONS . . . . . . . . . . . . . . . . . . . . 59

Gray Iron . . . . . . . . . . . . . . . . . . . . . 59

Ductile Iron . . . . . . . . . . . . . . . . 60

ACKNOWLEDGMENTS . . . . . . . . . . . . . . . . . . . 62

REFERENCES . . . . . . . . . . . . . . . . . . . . 63

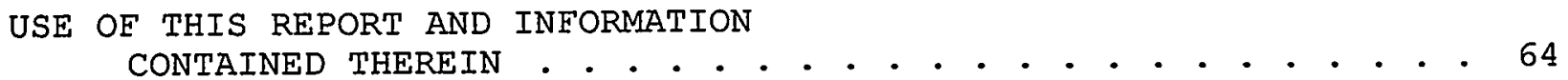

Publicity . . . . . . . . . . . . . . . . . . 64

Limitation of Liability . . . . . . . . . . . . . . . 64 


\section{PRODUCTION AND MACHINING OF THIN WALI GRAY AND DUCTILE CAST IRON}

\section{LIST OF TABLES}

Table Number

I

II

III

IV

V

VI

VII

VIII

IX

$\mathrm{X}$

$X I$

$X I I$

XIII

XIV

XV
Description

Generic Conditions That Affect Machinability

Compositions of Inoculants Used to Treat Gray Irons

Processing \& Composition of One-Inch Thick Gray Iron Plates (38-43 ksi Ult)

G8 Base Iron Nominal Composition-Induction Melt

Processing and Composition of One and Two Inches Thick Gray Iron Plates

Gray Iron Processing Effects on Drill Wear

Physical Properties of Selected Gray Iron Plates

Physical Properties of One-Inch Thick Gray Iron Plates (50-54 ksi Ult.)

Physical Properties of Two-Inch Thick Gray Iron Plates (43-45 ksi Ult)

Statistical Analysis of Copper, Nickel, Tin And Section Thickness on Machinability

Statistical Analysis of Copper and Nickel Effects on Ultimate Strength

D10 Base Iron Nominal Composition

Processing, Composition, and Properties of One-Inch Thick Ductile Iron Plates (71-96 Ksi Ult)

ANOVA Statistics for the Effect of Pearlite Stabilizers on Metal Removed to Squeal e 85 SFM

ANOVA Statistics for the Effect of Pearlite Stabilizers on Percent Pearlite Content in Matrix
Page

5

14

15

18

19

26

28

36

38

39

48

55

56 


\section{PRODUCTION AND MACHINING OF THIN WALI}

GRAY AND DUCTIIE CAST IRON

\section{LIST OF TABLES (Continued)}

Table Number

Description

$\underline{\text { Page }}$

XVI

ANOVA Statistics for the Effect of Pearlite

57

Stabilizers on Yield Strength 


\title{
PRODUCTION AND MACHINING OF THIN WALI GRAY AND DUCTILE CAST IRON
}

\author{
List of Figures
}

Figure Number

1

2

3

4

5

6

7

8

9

10

11

12
Description

Compression, shear and friction zones in cutting.

Schematic Stress Strain Curves for Aluminum, Gray Iron, Ductile Iron and Steel

Schematic Effects of Strength on Machinability of a Material

Curve Fit of Tool wear for 65-45-12 Induction Melted Iron, Normal Cool, Ladle 5 and 6 at 131 SMF (DBC). Spindle Speed 2000 RPM

Effect of Drill speed and Inoculation Additions on Metal Removed to squeal in Class 40 Gray Iron

Some physical properties of the selected gray irons. (A) Cell Count (B) Matrix hardess. (C) Brinell hardness.

Machinability of the selected gray irons at a drill surface speed of $98 \mathrm{sfm}$. (A) Metal volume removed to squeal at $98 \mathrm{sfm}$. (B) metal volume removed to produce 0.0065 inches flank wear at $98 \mathrm{sfm}$

Correlation between tool life at $98 \mathrm{sfm}$ and tensile strength - One Inch Thick Plates squeal in one-inch thick gray iron plates

Effect of drill speed on metal removed to squeal in two-inch thick gray iron plates

Compression stress-strain Curves of several gray iron samples

Correlation between ultrasonic velocity and 45

6

9

11

21

30 1 4

metal removed to squeal at $98 \mathrm{sfm}$ in gray irons

Page 


\section{PRODUCTION AND MACHINING OF THIN WAIL GRAY AND DUCTILE CAST IRON}

\section{List of Figures (Continued)}

\section{Eigure Number}

Description

Page

13

Effect of matrix structure on metal volume removed to drill squeal at various drill speeds

Effect of volume o pearlite on metal volume removed to drill squeal at $85 \mathrm{sfm}$ drill squeal at 85 sfm 


\title{
PRODUCTION AND MACHINING OF THIN WALL \\ GRAY AND DUCTILE CAST IRON
}

\begin{abstract}
The University of Alabama at Birmingham, in cooperation with the American Foundry Society, companies across North America, with support from the US Department of Energy, is conducting a project to develop an understanding of the factors that control the machinability of cast: gray and ductile iron. Differences of as much as $500 \%$ have been found in machinability have been observed at the same strength. The most machinable irons were those with a high cell counts and few carbonitride inclusions. Additions of tin and copper can be added to both gray and ductile iron to stabilize the pearlite, but excessive additions (above those required to produce the desired pearlite content) degrade the machinability.
\end{abstract}




\section{PRODUCTION AND MACHINING OF THIN WALI \\ GRAY AND DUCTILE CAST IRON}

\section{EXECUTIVE SUMMARY}

There is a growing demand for gray and ductile iron castings with consistent machinability. Hard-to-machine castings cause cutting tools to wear rapidly or break and may make it necessary to alter the machine tool settings. Tool wear leads to rapid loss of tolerances, deterioration in the machined surface quality, and machine downtime for tool replacement.

The University of Alabama at Birmingham, in cooperation with the American Foundry Society, companies across North America, with support from the US Department of Energy, undertook a project to develop an understanding of the factors that control the machinability of gray and ductile iron castings. The tasks in the project are summarized as follows:

1. Evaluate the effects of selected inoculants on the machinability of gray and ductile cast iron,

2. Determine feasible methods for controlling the occurrence of the microcarbides in gray and ductile iron castings,

3. Explore the feasibility of "quick response" indicators of machinability that might be used in foundries.

4. Demonstrate the improvements in machinability associated with foundry process control.

Some conclusions drawn from the study are summarized as follows:

Gray Iron

1. The irons with higher cell counts produced lower tool wear rates and the best tool life.

2. The eutectic cell counts were higher in the irons inoculated with the strontium-bearing ferrosilicons, and higher in the iron poured in green sand molds than in the irons poured in no-bake molds.

3. Higher tool wear rates were observed in irons having higher ultrasonic velocities and lower attenuations. The velocity and attenuation effects are probably related to the graphite size and shape. Additional work will be required to define the best graphite shape and methods for consistently achieving the preferred. shape. 
4. In general, inoculating additions containing larger amounts of highly oxidizable elements resulted in shorter tool lives. Possibly, that additions containing larger amounts of calcium, aluminum, barium, cerium and similar oxidizable elements reacted with air and moisture during pouring to produce abrasive oxides distributed throughout the metal.

5. Substantial differences were found in the machinability of gray irons having the same strength. The differences were sometimes as much as $500 \%$. The most machinable irons were those with a high cell count and few carbo-nitride inclusions.

6. The substitution of some copper with nickel resulted in an iron with better machinability and no sacrifice in strength.

7. Additions of tin and copper can be added to stabilize pearlite in iron, but excessive additions (above those required to produce the desired pearlite content) degrade the machinability.

8. Irons containing higher concentrations of microcarbides caused higher tool wear rates in laboratory machining experiments. Commercial castings reported by machine shops to be harder to machine were examined and were found to contain higher concentrations of microcarbides.

9. Processing changes have been implemented in commercial foundries using the results of the program and significant improvements in machinability obtained.

\section{Ductile Iron}

1. The lowest tool wear rates were obtained with matrices containing more ferrite. Tools could be used to remove $25 \mathrm{in}^{3}\left(410 \mathrm{~cm}^{3}\right)$ at speeds in the range of 65 to $118 \mathrm{sfm}(0.33$ to $0.60 \mathrm{~m} / \mathrm{s})$ in irons containing less than $20 \%$ pearlite.

2. The volume of metal that could be removed before drill failure progressively decreased as ferrite was replaced by pearlite.

4. A linear relationship was found between the yield strength and the ferrite content.

5. A statistical analysis of the data showed that both copper and tin significantly affect machinability. The addition of $0.38 \% \mathrm{Cu}$ accounted for 35\% of the tool life variability, and the addition of $0.10 \% \mathrm{Sn}$ accounted for $41 \%$ of the variation. Interactions between the copper and tin accounted for the remainder of the variation in tool life, which was $21 \%$.

Relationships were found between the addition of these elements, matrix microstructure, hardness, and yield strength. 


\section{INTRODUCTION}

A Thin Wall Iron Casting Production and Machining project was begun at the University of Alabama at Birmingham in 1995. The goals of the program were to (1) develop benchmark data on the machinability of gray and ductile iron, (2) compare benchmark data with data obtained from a variety of commercial castings, (3) define inclusions and other conditions that degrade machinability, (4) evaluate inoculants for their effectiveness in improving machinability, and (5) demonstrate approaches for mitigating factors that degrade machinability.

The general approach to the program consisted of building a data base by correlating the machinability of non-commercial castings produced in participating foundries with production conditions and casting compositions. Microstructures were examined and correlated with machining characteristics of each iron.

Tool life curves were developed using well-characterized High speed steel (HSS) drills. "Acceptable" and "hard-to-machine" castings were also obtained from participating companies to determine differences in microstructure and composition that might explain reported differences in machinability. The results obtained on "hardto-machine" castings were compared to results obtained in laboratory machining experiments.

Machinability, in this report, refers to either the tool wear rate or the number of holes drilled (volume of metal removed) before a specified amount of tool wear occurred on a tool flank. Tool wear may cause a loss of surface finish on the part being machined, but the surface finish was not the criteria being used in this program.

Metal Cutting Fundamentals

Many studies have been conducted to understand machinability of metals. In general, machining characteristics are classified by the type of chip formed using terms such as "continuous", "discontinuous" and "discontinuous with built-up-edge." Most metals exhibit reasonably predictable machinable behavior based on well-founded cutting theories $(1-4)$.

Machinability, as a material property, is not easily defined for gray and ductile irons, however, and this is especially true for drilling which involves more than one mechanism of metal removal and more than one type of chip. The historically used machinability tests (5-9) have not produced consistent results when some of the chips form as microscopic particles and others as continuous ribbons.

\section{Cutting of Gray Irons}

Many factors can influence tool life when machining gray and ductile iron. These include metallurgical conditions such as graphite size and distribution, composition, ferrite/pearlite ratio, cooling 
rate from the eutectic through the eutectoid temperatures, and the presence of either endogenous or exogenous inclusions. Several of the factors that influence machinability are listed in Table $I$, and the effects of some of these variables are schematically illustrated in Figure 1 .

Figure 1 represents a tool advancing through a metal part containing a variety of graphite flakes and abrasive macro-and microinclusions that might include oxides, carbides, nitrides, sand, or other materials. The advancing tool creates a compression zone below the tool flank and also ahead of the tool rake face. The shear and flow characteristics of the material are a function of the modulus, strength, work-hardening coefficient, chip-forming characteristics, and metal ductility.

Plastic deformation produced by the advancing tool in the work piece generates heat in the shear zone that must be dissipated either through the chip, workpiece, or the flank face. The metal being removed also impinges on the rake face of the tool and produces frictional heat. The heat and abrasion sometimes cause craters to develop on the tool rake face.

There is a normal force on the flank face of the tool caused by metal spring-back. Flank face friction associated with this force also produces heat that must be dissipated. Flank face heat, coupled with the presence of abrasive particles, causes flank face wear.

Several phases can be present in iron, and their volume and distribution have significant effects on tool wear. Massive carbides formed during solidification are hard and can obviously degrade the machining characteristics by chipping or breaking tool tips.

Some of the carbon dissolved in austenite during eutectic solidification must diffuse from the austenite and migrate to graphite flakes or nodules as the metal cools to the eutectoid temperature. The presence of elements that inhibit carbon diffusion reduces the rate of carbon transfer and produces austenite supersaturated with carbon. High cooling rates from the eutectic to the eutectoid temperature may not provide enough time for the carbon to diffuse to the graphite. Supersaturated austenite then decomposes in the eutectoid range to produce higher volumes of abrasive microcarbides in the pearlite.

Inoculant additions and solidification rates are also important. These two factors have significant effects on the graphite size and distribution which affect the carbon diffusion distance and the chip forming characteristics of the iron. The dissolved carbon must be able, in the time available as the iron cools from the eutectic to the eutectoid temperature, to diffuse from the austenite and attach itself to the eutectic graphite. Larger distances between graphite flakes and nodules require more time for carbon diffusion. 


\section{Table I}

Generic Conditions That Affect Machinability

Condition

Macro Inclusions

Sand

Chill

Dross

Reoxidation Products

Microcarbides

Modulus

Graphite Distribution

Compression Strength

Heat Generated on Rake Face

Sand Practice

Blast Practice
Effect

Chips and Breaks Tools

\author{
Abrades Tool Flank, Causes Wear \\ Increases Friction on Flank Face \\ Chip Size and length \\ Force Required to Deform Metal \\ May overheat the tool tip \\ Imbedded Sand \\ Work Hardened Surface
}

\section{METALLURGICAL CONDITIONS}

Cooling Rate through Eutectoid Range
Alloy Microcarbides:
(Fe, $\mathrm{Mo}, \mathrm{Cr}, \mathrm{Mn}) \mathrm{C}$
Trace Element Carbides:
$(\mathrm{Ti}, \mathrm{V}, \mathrm{Nb}) \mathrm{C}$
Trace Element Nitrides:
(Ti, V, Nb)N
Diffusion Inhibitors:
$\mathrm{Sn}, \mathrm{Sb}, \mathrm{As}$
Cell Growth Restrictors:
$\mathrm{Pb}$
Inoculation Practice 


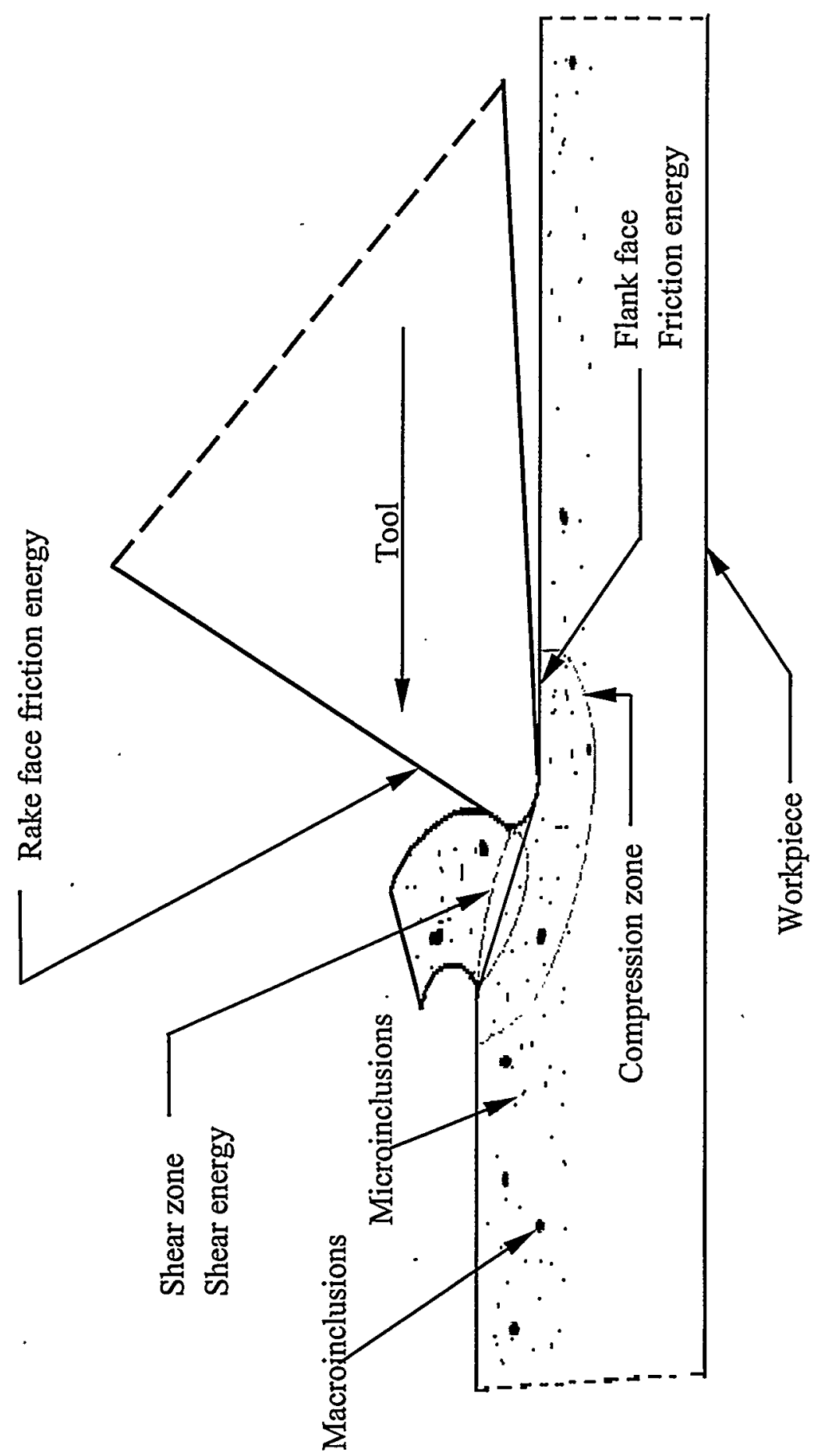

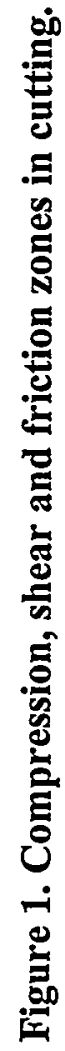


The graphite distribution also affects the mechanical strain that must be introduced to form a chip and the size of the chip formed. The volume and distribution of the graphite affects the friction

characteristics of the iron in contact with the rake and flank faces of the cutting tool. The friction characteristics affect the amount of heat produced that, in turn, affects the tool temperature. Higher tool temperatures cause faster tool wear.

Several minor phases can be present in iron, and their volume fraction and distribution have significant effects on tool life. Some phases that degrade machinability include (I) iron oxides and silicates formed during pouring; (2) carbides and ternary iron phosphides formed during eutectic solidification; (3) titanium, vanadium, and niobium carbides, nitrides, and carbonitrides formed by reactions in the iron; and (4) chromium and molybdenum carbides formed during cooling of the casting. Eutectic carbides formed during solidification have a well-known detrimental effect on machinability, but these have not been observed in any of the castings considered in this study.

Excessive cooling rates between the eutectic and eutectoid temperatures and elements that either inhibit carbon diffusion or form stable carbides (molybdenum, for example) reduce the rate of carbon transfer and can produce austenite that is supersaturated with carbon. (10) At or below the eutectoid temperature, the supersaturated austenite decomposes to produce abrasive micro-carbides distributed in the matrix.

The elastic modulus (stiffness) of the iron also has an important effect on tool life. High modulus irons push against the flank face of the cutting tool with more force (as illustrated in Figure 1) and produce more flank face heat at a constant feed rate which accelerates tool wear.

Pouring conditions are probably important because they determine the amount of oxygen and nitrogen that react with the iron during pouring. Maintaining a full sprue, having a properly designed sprue and runner system to minimize air entrainment, and using filters to control metal flow are important in minimizing the formation of oxides, silicates, and nitrides that degrade machinability.

Molding and metal handling practices can introduce oxides into the metal that abrade, wear, and chip cutting tools. Sand grains picked up from the mold and incorporated into the metal or that adhere to the surface of castings degrade machinability because of their abrasiveness.

Many factors can influence the machinability of iron, and one of the purposes of this study was to identify and rank by severity the phases and conditions that have undesirable effects. Corrective actions may then be taken to mitigate objectionable conditions. 
Tool Eailure Mechanisms

Heat, friction, and abrasion near the tool tip are the dominant causes for tool failure when machining cast iron. Heat is produced at the tool tip by friction on both the tool rake and flank faces and by shear energy transferred from the metal being machined.

Wear is accelerated by the presence of abrasive particles, and the wear rates increase with increasing tool rake or flank face area. Flank and rake face wear accelerates tool deterioration because the increased wear area in rubbing contact with the metal drives the tool temperature up and this reduces tool tip hardness.

The primary purpose of a coolant is to remove heat. Coolants contain surface active agents to reduce the liquid surface tension and aid in wetting both the metal and the tool, but little or no coolant actually gets to the tool tip to provide lubrication. The contact forces are simply too high.

The inherent properties of the material being machined also have important effects. The area under a stress - strain curve represents energy that must be applied to shear metal and form new surfaces. The required energy is a function of the strength, modulus, strain hardening coefficient, and strain to failure of the material.

Four schematic stress-strain curves are illustrated in Figure 2. Aluminum has a relatively low modulus of about 10 MPsi (69GPa) and cast alloys have a relatively low strain to failure, generally less than $10 \%$. Gray cast iron has a higher modulus, generally in the range of 14 to $18 \mathrm{MPsi}$ ( 97 to 125GPa) and a strain to failure of less than $1 \%$.

Ductile cast iron has a modulus of about 22-23 MPsi (153-160GPa) and the strain to failure that ranges form $3 \%$ to $18 \%$ or more depending on the exact grade. Ductile iron becomes progressively more difficult to machine as the strength increases.

Steel has the highest modulus and usually the greatest strain to failure. As a consequence, this metal is usually the most difficult to machine. Cutting speeds are relatively low compared to iron, and machining of steel is rarely attempted without the use of coolants. This progression from low modulus aluminum to gray iron, ductile iron, and steel involves progressively lower cutting speeds, and metal removal rates, especially if cutting fluids are not used.

Higher strength materials, and those that rapidly strain harden are less machinable. At a constant strength, materials and cutting conditions that produce short chips favor improved machinability. Lead and sulfur additions are often made to steel, and the graphite distribution is important in cast iron because of its effect on chip length. Finally, machinability (tool life) improves if abrasive particles can be removed from the metal. 
Steel

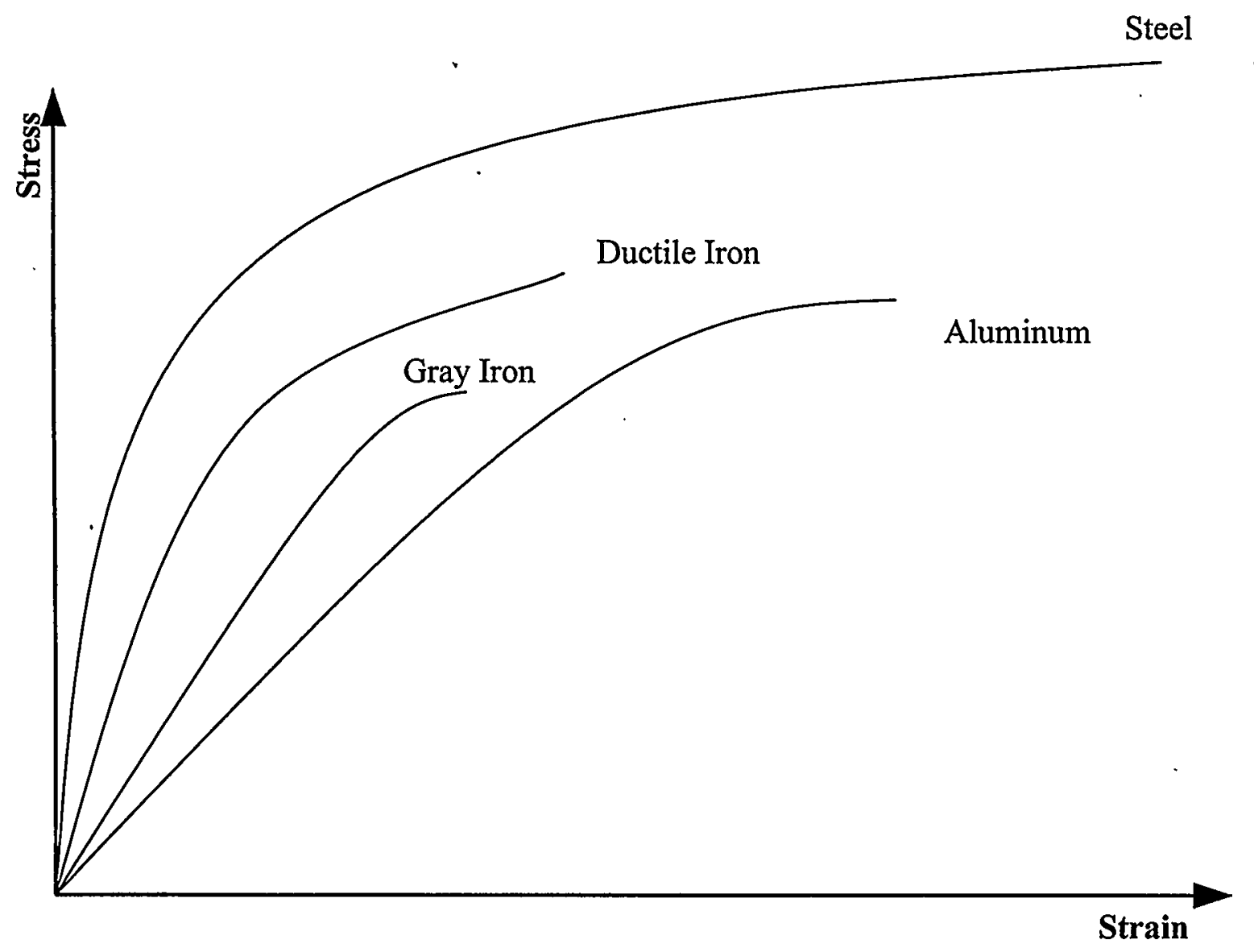

Figure 2. Schematic Stress Strain Curves for Aluminum, Gray Iron, Ductile Iron and Steel 
Machinability must be evaluated and compared to the strength of parts needed to meet design specifications. Machinability can be easily improved by increasing the carbon equivalent to produce more graphite and/or heat treating to produce more ferrite. These are acceptable approaches if the properties of the iron are still met.

Tool life is schematically illustrated in Figure 3 as a function of the strength of the material. Tool life generally decreases with increasing strength, but occasionally materials are encountered that have exceptionally good or exceptionally poor machinability at a given strength. One of the objectives of this project is to define those conditions that produce the "exceptionally good" and "poor" behavior at a constant strength.

In order to separate metallurgical effects from the variables in the machining process, it is necessary to standardize machining procedures and conditions. The majority of the work in this study was conducted using high-speed steel (HSS) drills. The material and evaluation procedure were chosen because about half of all metal removed from castings is done by drilling, and half of the drills used in the United States are made from high-speed steel.

Drilling is probably the most difficult of all machining operations. It is virtually impossible to get cutting fluids to drill tips without using a "pecking" procedure. Friction at the drill tip produces a large amount of heat, and chip removal from the hole is more difficult than from any other machining operation.

Thus, drilling represents a severe machining procedure that can be used to allow metallurgical effects to be separated with a reasonable volume of material. Other procedures can be used and larger volumes of material can be evaluated. 


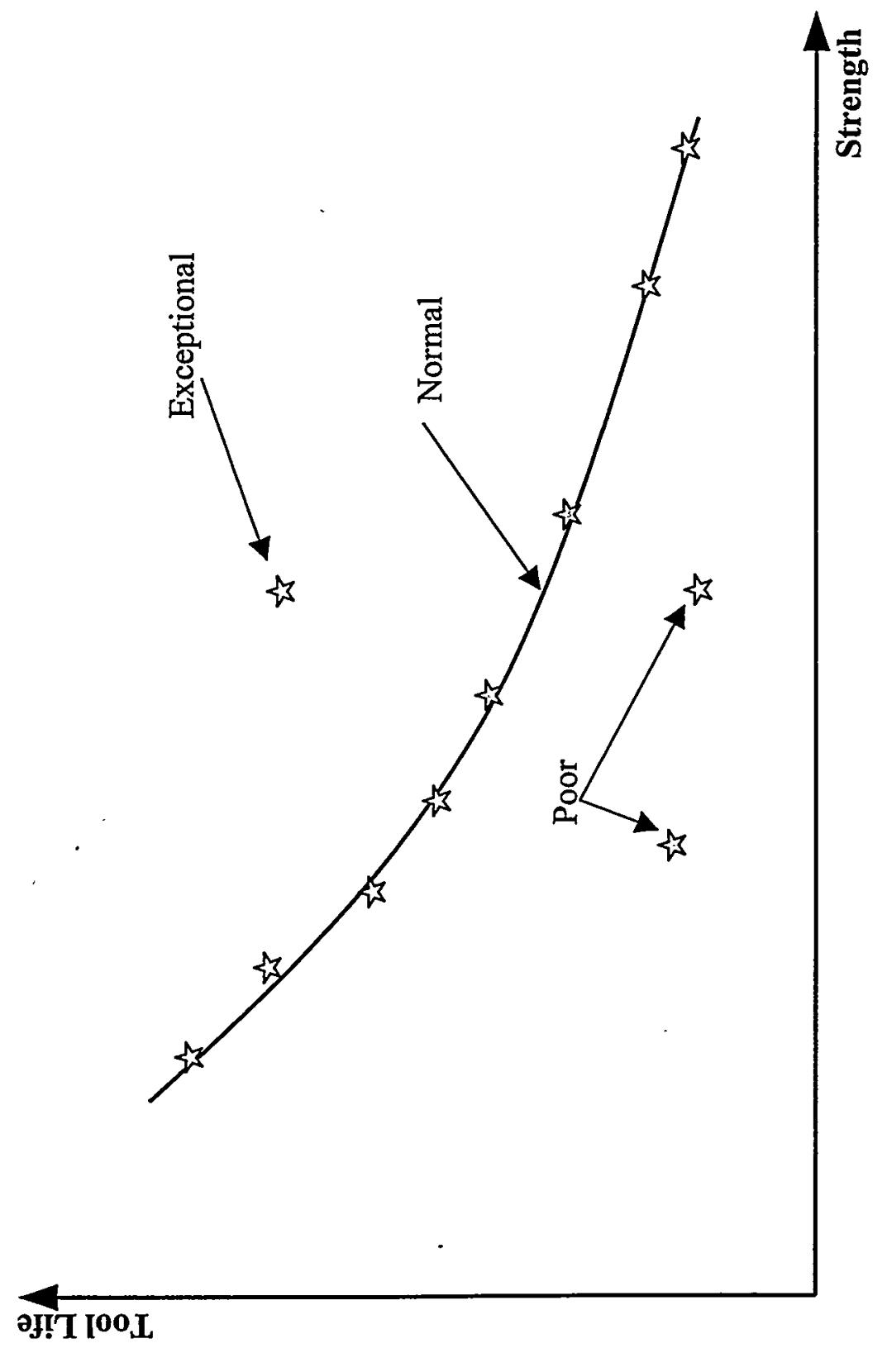

 
The objectives of this study were to:

1. Evaluate the effects of selected inoculants and compositional variables and cooling rate on the machinability of gray and ductile cast iron.

2. Determine feasible methods for controlling the occurrence of the microcarbides in gray and ductile iron castings.

3. Explore the feasibility of "quick response" indicators of machinability that might be used in foundries.

4. Demonstrate the improvements in machinability associated with foundry process control.

The procedures employed and the results obtained are summarized in the following sections of this report.

\section{Casting Production}

Two series of castings were produced to evaluate the effects of inoculation practice and mold material on machinability. Some of the inoculation results have been previously published. (11) However, additional work was completed in the past year, and all of the results are described here for completeness.

All of the castings were produced in commercial foundries experienced in the production of high quality castings. Each foundry and casting series was coded with a designation such as G10-7-1. The first part of the designation, G10, is a code for the foundry that produced the castings. The second part of the designation, 7, refers to the specific casting series in which a change was made in the process, and the last part of the designation, 1 , refers to the thickness of the plate produced for the study, it is one-inch (25mm) thick in this case.

\section{Effects of Inoculation and Mold Material on Machinability of Gray Iron}

Five series of castings were produced and evaluated. The first four series were produced in Foundry G8 to evaluate inoculants and mold material effects. Ladles of iron were inoculated with

(1) $0.2 \%$ additions of $50 \%$ ferrosilicon containing strontium and poured into green sand molds,

(2) $0.2 \%$ additions of $50 \%$ ferrosilicon containing strontium and poured into no-bake molds, 
(3) 75\% ferrosilicon containing calcium and aluminum and poured into no-bake molds, and

(4) $40 \%$ ferrosilicon containing approximately $9.1 \%$ cerium and poured into no-bake molds.

The compositions of the inoculants are presented in Table II. Both foundries used. induction melting furnaces, and three types of inoculating additions were used. The strontium bearing inoculants had a mesh size of $3 / 8$ by 32 ; the $75 \%$ ferrosilicon had a mesh size of $3 / 8$ by $30 ;$ and the cerium bearing inoculant had a mesh size of 5 by 30 . In most cases the addition amounted to $0.2 \%$ of the metal weight, although only $0.07 \%$ by weight of the cerium alloy was used.

Each mold at Foundry G8 contained six plate castings. Four molds were poured from each ladle to produce 24 plates, and two ladles were poured with each inoculant to produce a total of 48 plates using each treatment condition. The test castings were cooled to below 500F $(260 \mathrm{C})$ in the mold before shakeout.

The first four batches of castings were stress relieved for one hour at $1050 \mathrm{~F}$ (565C) which is the normal production practice in this foundry. Chill bars were also poured with each experimental condition. No significant chill was present in any sample. Ladle temperatures were measured on every tap before pouring, and the pouring temperatures were in the range of 2525-2550F (1385-1400C).

The fifth set of castings $(G 10-C-1)$ was poured in vertically parted green sand molds after inoculating with an addition of $0.2 \%$ foundry grade $75 \%$ ferrosilicon. These castings were also below the critical temperature at the time the molds were opened and the castings removed.

The designations of the irons produced in these casting trials is as follows.

\section{Series} Number

$\begin{array}{ll}1 & \text { green sand mold } \\ 2 & \text { No-bake mold } \\ 3 & \text { green sand Mold } \\ 4 & \text { No-bake mold } \\ 5 & \text { No-bake mold }\end{array}$

\section{Mold Type}

green sand mold

green sand Mold

No-bake mold

No-bake mold

\section{Inoculant}

$0.2 \% \operatorname{Sr} 75 \%$ FeSi

$0.2 \% \operatorname{Sr} 50 \%$ FeSi

$0.2 \% \operatorname{Sr} 50 \%$ FeSi

$0.2 \% \mathrm{Ca}-\mathrm{Al}$ 75\% FeSi

$0.2 \%$ Ce $40 \%$ FeSi

\section{Series} Designation

$$
\begin{aligned}
& \text { GI0-C-1 } \\
& \text { G8-U2-1 } \\
& \text { G8-0 -1 } \\
& \text { G8-F2-1 } \\
& \text { G8-C2-1 }
\end{aligned}
$$

The compositions and process variables associated with each of the heats is presented in Table III. The metal was poured at about $2525 \mathrm{~F}(1385 \mathrm{C})$ in most cases, but a slightly higher pouring temperature of 2550F (1400C) was used in foundry G10. The shake-out time was a minimum of 40 minutes to be sure that the castings were below the eutectoid temperature when shaken out. 
TABLE II

Compositions of Inoculants Used to Treat Gray Irons

\begin{tabular}{llll} 
Element & $\begin{array}{c}\mathrm{Sr} 50 \% \mathrm{Si} \\
\text { Inoculant } \\
(\%)\end{array}$ & $\begin{array}{c}\mathrm{Ce} \mathrm{40 \%} \mathrm{Si} \\
\text { Inoculant } \\
(\%)\end{array}$ & $\begin{array}{c}\text { Ca Al 75\% Si } \\
\text { Inoculant } \\
(\%)\end{array}$ \\
\hline $\mathrm{Si}$ & 46.59 & 41.08 & 77.01 \\
$\mathrm{Al}$ & 0.36 & 0.35 & 0.80 \\
$\mathrm{Ca}$ & 0.014 & 0.96 & 1.44 \\
$\mathrm{Mn}$ & 0.41 & 0.33 & 0.11 \\
$\mathrm{Sr}$ & 0.99 & 0.072 & 0.093 \\
$\mathrm{P}$ & 0.028 & 0.44 & 0.022 \\
$\mathrm{Ti}$ & $-\ldots--$ & 0.08 & 0.051 \\
$\mathrm{Ce}$ & $-\ldots$ & 9.08 &.--- \\
$\mathrm{Fe}$ & balance & balance & balance
\end{tabular}




\section{Table III}

Processing and Composition of One Inch Thick Gray Iron Plates (38-43ksi Ult.)

\begin{tabular}{|c|c|c|c|c|c|}
\hline Iron Designation & G10-C-1 & G8-U2-1 & G8-0-1 & G8-F2-1 & G8-C2-1 \\
\hline Furnace & Induct & Induct & Induct. & Induct & Induct \\
\hline \multicolumn{6}{|l|}{ Composition } \\
\hline $\mathrm{C}$ & 3.35 & 3.26 & 3.30 & 3.26 & 3.26 \\
\hline $\mathrm{Si}$ & 2.33 & 1.93 & 1.99 & 1.93 & 1.93 \\
\hline $\mathrm{Mn}$ & 0.73 & 0.63 & 0.59 & 0.63 & 0.63 \\
\hline$S$ & 0.10 & 0.09 & 0.085 & 0.09 & 0.09 \\
\hline $\mathrm{P}$ & 0.05 & 0.03 & 0.029 & 0.03 & 0.03 \\
\hline $\mathrm{Cr}$ & 0.00 & 0.21 & 0.17 & 0.21 & 0.21 \\
\hline Mo & ---- & 0.18 & 0.28 & 0.18 & 0.18 \\
\hline $\mathrm{Ni}$ & ---- & 0.10 & 0.09 & 0.10 & 0.10 \\
\hline $\mathrm{Cu}$ & 0.24 & 0.60 & 0.51 & 0.75 & 0.75 \\
\hline $\mathrm{Ti}$ & --- & Resi. & 0.015 & Resi. & Resi. \\
\hline $\mathrm{Sn}$ & 0.04 & ----- & -.-- & ---- & $\cdots$ \\
\hline $\mathrm{Sb}$ & 0.03 & ----- & ---- & ---- & ----- \\
\hline Inoculant Type & $75 \% \mathrm{Si}$ & Sr50 & Sr50 & $75 \% \mathrm{Si}$ & Ce40Si \\
\hline Amount (\%) & 0.2 & 0.20 & 0.2 & $0.2 \%$ & 0.07 \\
\hline Mold & GS & AS & GS & AS & AS \\
\hline Pour Temp & 2550 & 2525 & 2525 & 2525 & 2525 \\
\hline Shakeout time(min.) & 40 & 60 & 86 & 60 & 60 \\
\hline $\mathrm{BHN}$ (mean) & 201 & 221 & 210 & 192 & 232 \\
\hline Std.dev. & 3.5 & 5.9 & 8.6 & 3.8 & 6.6 \\
\hline Tensile Yield(ksi) & 32.2 & 36.19 & 37.15 & 33.32 & 36.86 \\
\hline Ultimate(ksi) & 38.8 & 42.08 & 42.73 & 38.21 & 38.21 \\
\hline \multicolumn{6}{|l|}{ Compression } \\
\hline stress at 0.2 Strain $(\mathrm{ksi})$ & i) 30.00 & 30.50 & 51.00 & 30.50 & 32.30 \\
\hline stress at 0.2 Offset $(\mathrm{ksi})$ & i) 53.00 & 58.70 & 66.30 & 59.00 & 59.00 \\
\hline Ultimate(ksi) & 119.60 & 128.60 & 142.50 & 122.60 & 130.70 \\
\hline $\operatorname{Density}(g / c c)$ & 7.216 & 7.224 & 7.216 & 7.232 & 7.231 \\
\hline Holes to squeal $98 \mathrm{sfm}$ & m 702 & 644 & 400 & 140 & 87 \\
\hline Metal removed $\left(\mathrm{in}^{3}\right) 2$ & 25.84 & 23.71 & 14.73 & 5.15 & 3.20 \\
\hline
\end{tabular}


All castings used in this study were cast as plates approximately 8 inches $(200 \mathrm{~mm})$ by 12 inches $(300 \mathrm{~mm})$ with a thickness of either one or two-inches (25 or $50 \mathrm{~mm}$ ). The plan area where holes were drilled was approximately 7 by 11 inches (175 by $280 \mathrm{~mm})$, and 180 holes were drilled per plate. The holes were drilled on half inch (12.7mm) centers to avoid strain hardening effects in adjacent holes.

The tool wear experienced during drilling was measured using procedures described in a later section of this paper. In general, the procedure consisted of mounting the plate on CNC milling machine and drilling through the plate. There were recessed panes on the bottom of each plate to prevent the drill from penetrating the CNC bed. Drills were periodically removed from the $\mathrm{CNC}$ and the amount of drill wear measured as more holes were drilled.

The Brinell hardness, yield strength, ultimate strength, compressive strength, density, and tool life at 98 surface feet per minute (SFM) $(0.50 \mathrm{~m} / \mathrm{s})$ obtained in machining trials on castings produced with each inoculant are also presented in Table III. Three of the irons had a strength of $38 \mathrm{ksi}(264 \mathrm{MPa})$, and two had strengths of $42 \mathrm{ksi}(292 \mathrm{MPa})$. The hardness ranged from 201 to $232 \mathrm{BHN}$, but there was no clear relationship between hardness and strength.

The tool life progressively decreased from 702 to 87 holes per drill at $98 \mathrm{sfm}(0.50 \mathrm{~m} / \mathrm{s})$ in going from G10-C-1 to G8-U2-1, G8-0-1, G8F2-1, and finally to G8-C2-I. There was a decrease in tool life of about $90 \%$ throughout this progression even though the strengths and compositions of the irons were similar.

\section{Effects of Composition and Section Size}

A second series of castings was produced at Foundry $G 8$ to evaluate the effects of selected composition variables and casting thickness on machinability. The base iron for these castings was prepared from a charge made up from the following materials:

$\begin{array}{ll}\text { Slitter stock } & 33.2 \% \\ \text { Gray Cast Iron Returns } & 54.4 \% \\ \text { Gray Cast Iron Borings } & 10.6 \% \\ 50 \% \text { Ferrosilicon } & 0.8 \% \\ \text { Low Sulfur Carbon } & 0.9 \%\end{array}$

The silicon, copper, nickel, sulfur, and tin additions were made directly to the stream during tapping. A pin tube sample was taken to determine oxygen and nitrogen concentrations.

Chill bars were also poured with each experimental condition with no significant chill present in any sample. Ladle temperatures were measured on every tap, and the ladle temperature maintained in the range of $2460-2500 \mathrm{~F}$ (1350-1370C). Six molds were poured from each 
ladle and a ladle button was taken on the first and last ladles tapped for chemical analysis.

One- and two-inch (25 and 50mm) thick castings were produced and evaluated. Compositional variations were made according to the statistical matrix outlined in Table IV and included variations in tin, copper, nickel, and molybdenum concentrations. Composition and processing data on the one and two inches $(25 \mathrm{~mm}$ and $50 \mathrm{~mm}$ ) thick cast plates is presented in Table $\mathrm{V}$.

These castings were knocked out of the mold after two hours. A shake-out effect going through eutectoid transformation was not evident when looking at shake-out temperatures of 600-1000F (315$540 \mathrm{C})$.

\section{Ductile Iron Casting Production}

Four sets of 65-45-12 grade ductile iron plates were poured, and each set was inoculated with a different type or amount of the late addition. Metal was melted in a nine-ton coreless induction furnace, tapped over magnesium ferrosilicon, post inoculated, and delivered to the pouring line in the treatment ladle.

\section{Machinability Evaluation Procedures}

One-quarter inch (6.35mm) diameter, M7 high speed steel (HSS) drills were used to perform the tool life (wear) experiments. All drills were from the same production lot, heat treated at the same time, and ground on the same drill producing machine.

Each drill was examined under a low power microscope for uniformity of the cutting edge before being used. The presence of a chipped cutting edge or other unusual feature caused the drill to be discarded. The drill was locked into a drill holder, and the initial shape of the drill tip digitized from an image projected by an optical comparator.

The drill was accurately positioned in a drill holder in such a manner that the one cutting edge was parallel to the horizontal axis. A positioning procedure was. established to ensure that drills could always be examined at the same location and that the reference line of the cutting edge was not lost. The holder was then placed in a programmed CNC mill and holes drilled through experimental castings.

The drill holder (and drill) were periodically removed from the CNC machine and the drill wear pattern recorded using the same digitization process. The drill flank wear was recorded as a function of the number of holes drilled. Preliminary measurements and statistical analysis were performed to determine whether wear on both cutting edges should be digitized and averaged. The results of this early investigation showed convincingly that the wear land on the two cutting edges was identical. 


\section{Table IV}

G8 Base Iron Nominal Composition - Induction Melt

$\begin{array}{ll}\mathrm{C} & 3.18 \\ \mathrm{Si} & 2.00 \\ \mathrm{Mn} & 0.55 \\ \mathrm{Ni} & 0.05 \\ \mathrm{Cu} & 0.35 \\ \mathrm{Cr} & 0.20 \\ \mathrm{Mo} & 0.15 \\ \mathrm{Ti} & 0.015 \\ \mathrm{Sn} & 0.010\end{array}$

EXPERIMENTAL MATRIX

$\begin{array}{llllll}\text { Heat } & \underline{\mathrm{Sn}} & \underline{\mathrm{Mo}} & \underline{\mathrm{Cu}} & \underline{\mathrm{Ni}} & \underline{\mathrm{Cu}+\mathrm{Ni}} \\ (1) & 0.01 & 0.16 & 0.69 & 0.06 & 0.75 \\ (2) & 0.08 & 0.16 & 0.43 & 0.26 & 0.69 \\ (5) & 0.01 & 0.29 & 0.41 & 0.24 & 0.65 \\ (6) & 0.08 & 0.29 & 0.68 & 0.06 & 0.74\end{array}$

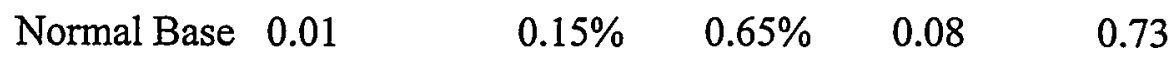

Pour Two Plate Thicknesses of Each Composition to Obtain Different Cooling Rates 


\section{Table V}

Processing and Composition of One and Two Inches Thick Gray Iron Plates

\begin{tabular}{|c|c|c|c|c|}
\hline Iron Designation & G8-5 & G8-1 & G8-2 & G8-6 \\
\hline Furnace & Induct & Induct & Induct. & Induct \\
\hline \multicolumn{5}{|l|}{ Composition } \\
\hline $\mathrm{C}$ & 3.16 & 3.18 & 3.17 & 3.16 \\
\hline $\mathrm{Si}$ & 2.02 & 1.97 & 1.95 & 2.03 \\
\hline $\mathrm{Mn}$ & 0.55 & 0.54 & 0.53 & 0.55 \\
\hline$S$ & 0.07 & 0.07 & 0.07 & 0.07 \\
\hline $\mathrm{P}$ & 0.02 & 0.02 & 0.02 & 0.02 \\
\hline $\mathrm{Cr}$ & 0.16 & 0.15 & 0.15 & 0.16 \\
\hline Mo & 0.29 & 0.16 & 0.16 & 0.29 \\
\hline $\mathrm{Ni}$ & 0.24 & 0.06 & 0.26 & 0.06 \\
\hline $\mathrm{Cu}$ & 0.41 & 0.69 & 0.43 & 0.68 \\
\hline $\mathrm{Ti}$ & 0.011 & 0.01 & 0.011 & 0.011 \\
\hline $\mathrm{Sn}$ & 0.014 & 0.014 & 0.079 & 0.085 \\
\hline $\mathrm{Sb}$ & - & - & 一 & - \\
\hline Inoculant Typ. & Sr50 & Sr50 & Sr50 & Sr50 \\
\hline Amount (\%) & 0.2 & 0.2 & 0.2 & 0.2 \\
\hline Mold & GS & GS & GS & GS \\
\hline Pour Tèmp & 2525 & 2525 & 2525 & 2525 \\
\hline Shakeout time(min.) & 128 & 128 & 128 & 128 \\
\hline
\end{tabular}


Drillability experiments were conducted using at least four drill speeds with each material, and either two or three drills were used at each speed selected. All experiments were performed at the same feed per revolution (0.009in or $0.23 \mathrm{~mm}$ per rev.) and 180 holes were drilled in each plate. Holes were drilled until the drill either failed by squeal or until the drill had been used to produce 720 holes.

All hole locations were center-drilled to a depth of 0.02 inches $(0.5 \mathrm{~mm})$ to form a pilot hole prior to drilling. The pilot hole minimized drill bending which might be caused by asperities on the cast surface. The drill chisel was guided by the pilot hole, but the pilot hole was so shallow that the cutting edge encountered the ascast surface.

The flank wear area was digitized from the chisel edge to the lip of the drill on an optical comparator. The wear pattern was digitized, recorded, and stored on a computer connected to the optical comparator. The flank wear areas were divided by the flank length to provide a measure of the average flank wear. Average wear is defined as the total wear area divided by the distance from the chisel edge to the drill edge. The average wear values were used to prepare tool flank wear curves, such as illustrated for an ASTM 60:45:12 ductile iron in Figure 4.

Four features of the tool wear curve were examined when examining drill wear data. This included the number of holes drilled before drill failure, the number of holes drilled to produce a specified amount of flank wear $(0.005$ inches [0.13mm] for ductile iron and 0.0065 inches $[0.17 \mathrm{~mm}]$ for gray iron), the rate of drill wear (mils per 100 holes drilled [ $1 \mathrm{mil}=0.001 \mathrm{in} .=0.025 \mathrm{~mm}]$ ), and the average volume of metal removed per drill. These values are given in the data box in Eigure 4. The data obtained with each drill are plotted with different symbols so the wear on any drill can be followed if desired.

The solid line drawn through each data set represents the best linear fit to the flank wear data, and the dashed lines on either side of the solid line represent one standard deviation about the mean wear line. The slope of the wear line is the wear rate expressed in mils per 100 holes drilled. The rate of tool wear always increased with cutting speed. Higher cutting speeds produce heat at the tool tip at a higher rate, and the rate of heat diffusion from the tool tip is insufficient to prevent overheating.

Two criteria were used to define drill failure in the current study. These were the number of holes drilled to produce an average flank wear of 6.5 mils $(0.0065$ inches or $0.17 \mathrm{~mm})$ or 5 mils $(0.005$ inches or $0.127 \mathrm{~mm}$ ) in gray and ductile iron, respectively, and the number of holes that could be drilled before drill squeal.

The tool wear rate is a function of the speed of cutting and the metallurgical characteristics of the material being drilled. The important metallurgical characteristics include pearlite content, 


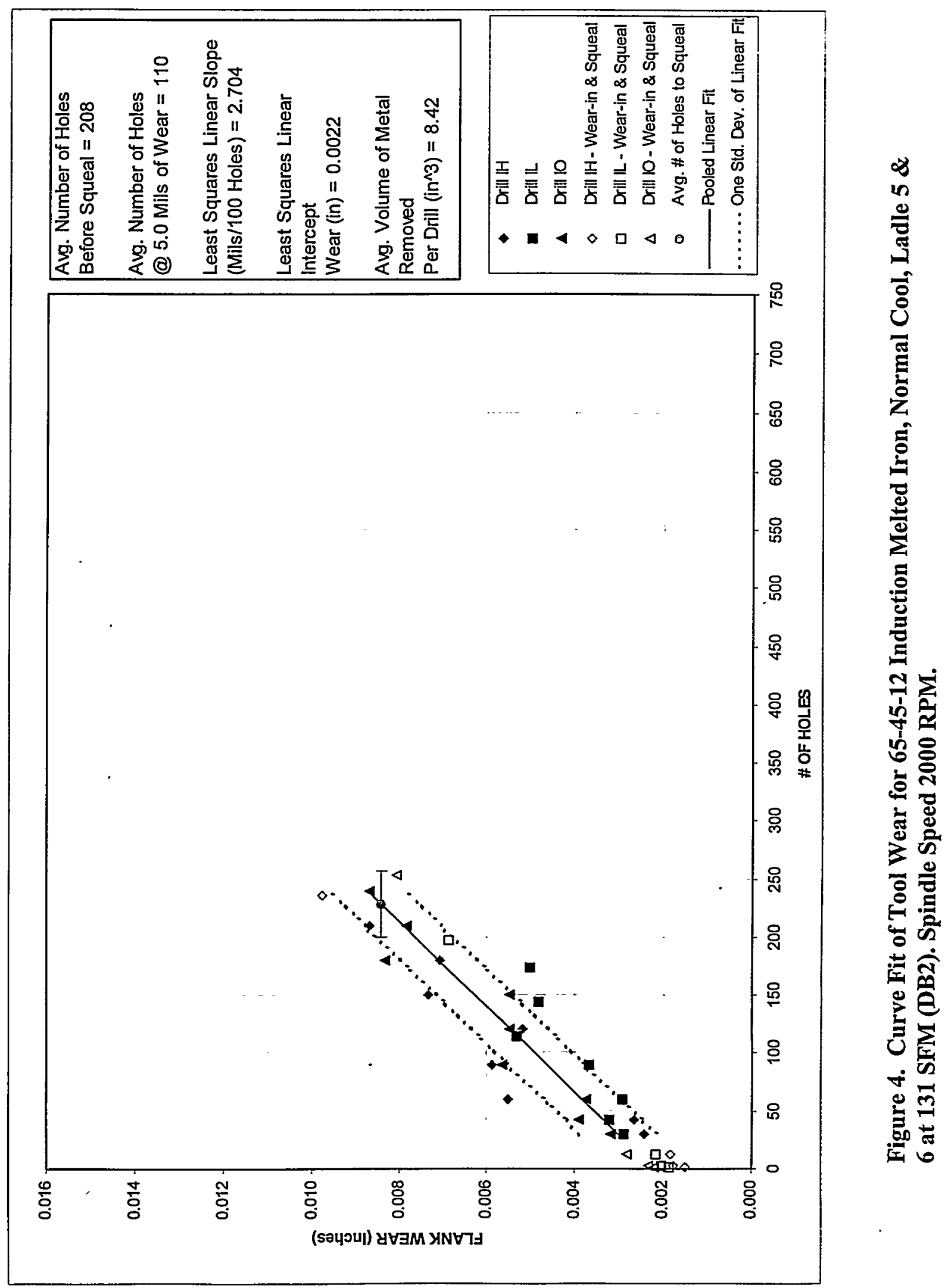


pearlite micro-hardness and microcarbide content, graphite spacing, and the modulus, yield, tensile, and compressive strengths of the iron. Triplicate compression and tension specimens were removed from a minimum of two plates for data replication.

\section{Specimen Microscopy}

The microstructure of each material and certain physical and chemical properties of each iron were determined. The properties of interest included (1) microstructure, (2) matrix and surface microhardness, (3) eutectic cell count, (4) Rockwell hardness (5) density, and (6) chemical composition. Procedures for mounting and examining the specimens used for microstructure have been previously published. (12)

\section{Casting Hardness}

Brinell Hardness. Brinell hardness indentations were made using a 3000 $\mathrm{kg}$ load on plates that had been ground to produce plane and parallel surfaces. Approximately 0.06 inches [1.6mm] was ground from the top of the plate (the drill entry surface), and the recesses were similarly ground from the bottom of the plate to produce a plate with plane and parallel surfaces for hardness measurements.

The hardness map was prepared by making 45 hardness indentations on a one-inch (25mm) grid pattern. The diameters of each indentation were determined using a calibrated laser reading device.

Matrix Microhardness. The matrix microhardness was determined to examine the possibility of a correlation between pearlite hardness and machinability. Pearlite microhardness was measured using a diamond indenter with a $50 \mathrm{~g}$ load. A distance of three indentation diameters was maintained from other microstructural features. Twenty measurements were made on each specimen, and the lowest ten values were dropped since the indenter might have encountered a graphite flake just below the polished surface.

\section{Ultrasonic Evaluation}

Two transducers were aligned at the same axis and powered by the ultrasonic pulser receiver. Ultrasound was generated by one of the transducers and received by another one. The received ultrasonic signal was sent to a digital oscilloscope and then to a computer for data analysis.

The reference signal was measured first when the two transducers were put face to face. The test plate was put in between the transducers and the signal from the plate was captured. Constant coupling and pressure were applied between the transducers and test plate to make sure consistent signals were obtained.

The ultrasonic time delay in the test plate were calculated by 
comparing the reference signal and the signal from the test plate. The peak heights of the signals were also found. The ultrasonic

attenuation coefficient and ultrasonic velocity were calculated by the following formulas.

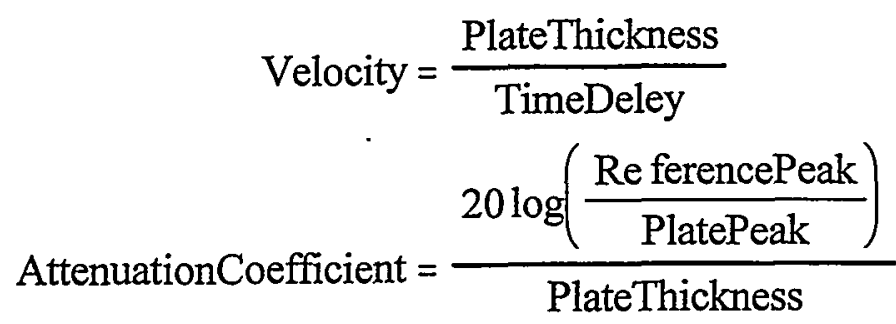




\section{RESULTS AND DISCUSSION}

The volume of metal removed to drill squeal in the one-inch (25m) thick plate castings inoculated with different materials and cast in no-bake and green sand molds is illustrated in Figure 5 as a function of drill speed and inoculant addition. The flank wear criteria produced results that paralleled the results obtained using the drill squeal criteria.

Several features of tool life are evident from this data. The drill wear curves converged at a speed of about $110 \mathrm{sfm}(0.56 \mathrm{~m} / \mathrm{s})$ and there was relatively little difference in tool life as a function of either speed or inoculant above $110 \mathrm{sfm}(0.56 \mathrm{~m} / \mathrm{s})$. Below $110 \mathrm{sfm}$ $(0.56 \mathrm{~m} / \mathrm{s})$, more metal could be removed from Gl0-C-1 (25.8 in ${ }^{3}$, $422.8 \mathrm{~cm}^{3}$ ) before reaching the wear criteria among all of the experimental irons, followed by the iron inoculated with the strontium-bearing ferrosilicon and poured into no-bake molds. This was followed by the iron inoculated by the same material and poured in green sand molds.

A smaller volume of metal could be removed from the irons inoculated with the 75\% foundry grade ferrosilicon $\left(5.15 \mathrm{in}^{3}, 84.4 \mathrm{~cm}^{3}\right)$ and the cerium-bearing ferrosilicon $\left(3.2 \mathrm{in}^{3}, 52.4 \mathrm{~cm}^{3}\right)$ at Foundry $\mathrm{G} 8$ before reaching an average flank wear of 0.0065 inches $(0.17 \mathrm{~mm})$. A greater volume of material (more holes) can usually be drilled at a lower speed. Heat is produced at a lower rate and can be dissipated at a sufficient rate to keep the tool tip at a moderate temperature.

If a constant drill speed were being used on a transfer line, for example $98 \mathrm{sfm}(0.50 \mathrm{~m} / \mathrm{s})$, the type of inoculant could be selected such that the required volume of metal could be removed prior to tool change. If the minimum number of holes to be drilled was 100 (3.68in ${ }^{3}$, $60.3 \mathrm{~cm}^{3}$ ) before a tool change, then either the strontium or foundry grade ferrosilicon would be suitable inoculants. If the number of holes required was larger, for example $200\left(7.36 \mathrm{in}^{3}, 120.7 \mathrm{~cm}^{3}\right)$, and if the tool speed could be varied, then a strontium-bearing material might be chosen to allow the drill to be operated at a higher speed.

Process effects on drill wear are presented in Table VI. The headers at the top of each column indicate the peripheral drill speed in surface feet per minute ( $\mathrm{sfm}$ ) and the bottom number indicates the speed in revolutions per minute (rpm), i.e., 85/1300 indicates that the drill is running at 85 surface feet per minute $(0.43 \mathrm{~m} / \mathrm{s})$ and at $1300 \mathrm{rpm}(136 \mathrm{rad} / \mathrm{s})$. Progressive columns contain wear data at higher speeds of $98,111,124$, and $144 \mathrm{sfm}(0.50,0.56,0.63$ and $0.73 \mathrm{~m} / \mathrm{s})$.

Under each header are columns indicating the number of holes drilled to drill "squeal", the slope of the wear curve, and the number of holes drilled to produce an average flank wear of 0.0065 inches $(0.17 \mathrm{~mm})$. The slope is reported in mils $(0.025 \mathrm{~mm})$ of average tool wear per hundred holes drilled. The rate of tool wear increased with inoculating additions of $75 \%$ foundry grade ferrosilicon and cerium- 


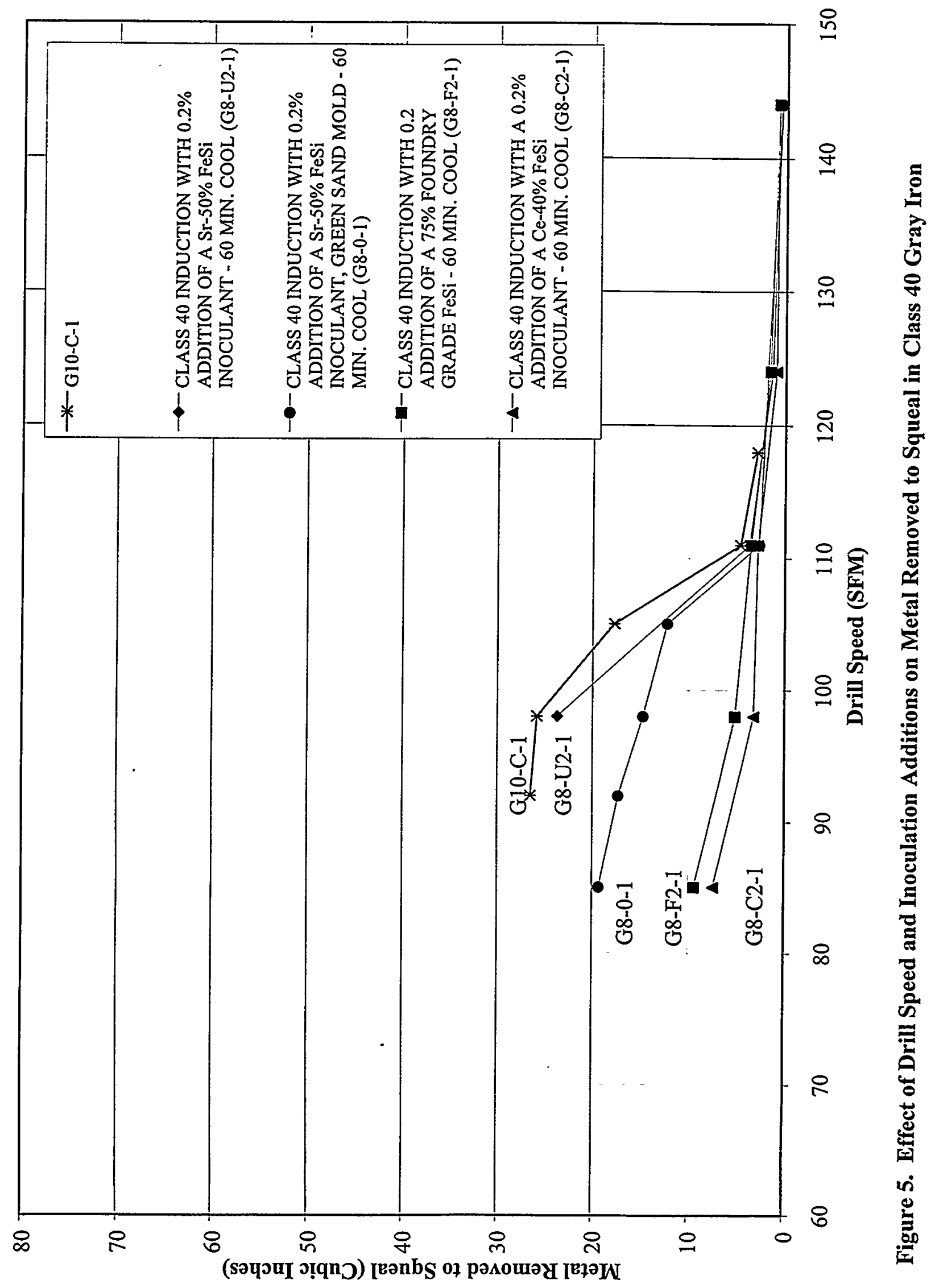




\section{Table VI}

Gray Iron Processing Effects on Drill Wear

\begin{tabular}{|c|c|c|c|c|c|c|c|c|c|c|c|c|c|c|c|}
\hline \multirow{2}{*}{$\begin{array}{l}\text { Speed (SFM/rpm) } \\
\text { Iron Designation } \\
\text { Inoculant and Mold Type }\end{array}$} & \multicolumn{3}{|c|}{$85 / 1300$} & \multicolumn{3}{|c|}{$98 / 1500$} & \multicolumn{3}{|c|}{$111 / 1700$} & \multicolumn{3}{|c|}{$124 / 1900$} & \multicolumn{3}{|c|}{$144 / 2200$} \\
\hline & VTS & Slope & $\begin{array}{l}.0065 \\
\text { Wear }\end{array}$ & VTS & Slope & $\begin{array}{l}.0065 \\
\text { Wear }\end{array}$ & VTS & Slope & $\begin{array}{l}.0065 \\
\text { Wear }\end{array}$ & VTS & Slope & $\begin{array}{l}.0065 \\
\text { Wear }\end{array}$ & VTS & Slope & $\begin{array}{l}.0065 \\
\text { Wear }\end{array}$ \\
\hline $\begin{array}{l}\text { G10-C-1 } \\
\text { (Std Dev) }\end{array}$ & & & & $\begin{array}{l}25.84 \\
(0.77)\end{array}$ & 0.14 & $\begin{array}{r}11.60 \\
(3.46)\end{array}$ & $\begin{array}{c}4.64 \\
(1.44)\end{array}$ & 0.23 & $\begin{array}{c}5.30 \\
(1.07)\end{array}$ & & & & & & \\
\hline $\begin{array}{l}\text { G8-U2-1: } 0.2 \% \text { Sr } 50 \% \text { FeSi } \\
\text { (Std Dev) } \\
\text { Poured in No-Bake Molds }\end{array}$ & & & & $\begin{array}{l}23.71 \\
(3.94)\end{array}$ & 0.21 & $\begin{array}{l}12.22 \\
(1.95)\end{array}$ & $\begin{array}{c}3.68 \\
(1.40)\end{array}$ & 0.51 & $\begin{array}{c}2.72 \\
(1.91)\end{array}$ & $\begin{array}{c}1.33 \\
(0.52)\end{array}$ & 1.26 & $\begin{array}{c}2.06 \\
(0.85)\end{array}$ & $\begin{array}{c}0.55 \\
(0.18)\end{array}$ & & $\begin{array}{c}2.32 \\
(0.48)\end{array}$ \\
\hline $\begin{array}{l}\text { G8-0-1: } 0.2 \% \text { Sr } 50 \% \mathrm{FeSi} \\
\text { (Std Dev) } \\
\text { in Green Sand Molds }\end{array}$ & $\begin{array}{l}19.36 \\
(0.96)\end{array}$ & 0.25 & $\begin{array}{c}7.07 \\
(2.02)\end{array}$ & $\begin{array}{l}14.73 \\
(2.61)\end{array}$ & 1.41 & $\begin{array}{c}7.66 \\
(5.74)\end{array}$ & $\begin{array}{c}2.69 \\
(0.66)\end{array}$ & 0.28 & $\begin{array}{l}2.43 \\
(2.06)\end{array}$ & & & & $\begin{array}{c}0.48 \\
(0)\end{array}$ & 1.87 & $\begin{array}{c}1.73 \\
(0.52)\end{array}$ \\
\hline $\begin{array}{l}\text { G8-F2-1: } 0.2 \% 75 \% \text { FeSi in } \\
\text { (Std Dev) } \\
\text { No Bake Molds }\end{array}$ & $\begin{array}{c}9.39 \\
(10.49)\end{array}$ & 0.37 & $\begin{array}{c}5.56 \\
(4.05)\end{array}$ & $\begin{array}{c}5.15 \\
(1.66)\end{array}$ & 0.60 & $\begin{array}{c}5.96 \\
(3.76)\end{array}$ & $\begin{array}{c}3.53 \\
(1.14)\end{array}$ & 1.58 & $\begin{array}{c}3.06 \\
(1.29)\end{array}$ & $\begin{array}{c}1.55 \\
(0.44)\end{array}$ & 1.01 & $\begin{array}{c}3.76 \\
(0.63)\end{array}$ & $\begin{array}{c}0.77 \\
(0)\end{array}$ & 1.33 & $\begin{array}{c}2.98 \\
(0.11)\end{array}$ \\
\hline $\begin{array}{l}\text { G8-C2-1: } 0.2 \% \text { Ce } 40 \% \text { FeSi } \\
\text { (Std Dev) } \\
\text { No Bake Molds }\end{array}$ & $\begin{array}{c}7.44 \\
(4.68)\end{array}$ & 0.54 & $\begin{array}{c}2.25 \\
(1.21)\end{array}$ & $\begin{array}{c}3.20 \\
(1.10)\end{array}$ & 1.47 & $\begin{array}{c}2.80 \\
(1.40)\end{array}$ & $\begin{array}{c}2.87 \\
(0.18)\end{array}$ & 2.15 & $\begin{array}{c}2.02 \\
(0.96)\end{array}$ & $\begin{array}{c}0.96 \\
(0.44)\end{array}$ & 1.09 & $\begin{array}{c}1.36 \\
(1.10)\end{array}$ & $\begin{array}{c}0.81 \\
(0.04)\end{array}$ & 2.74 & $\begin{array}{c}1.33 \\
(0.04)\end{array}$ \\
\hline
\end{tabular}

VTS = metal volume removed to tool squeal / (sd), in cubic inches

Slope $\quad=\quad$ average tool wear rate in mils per cubic inches

0.0065 wear $=$ holes drilled to produce an average of 0.0065 inches flank wear / (sd)

sd $\quad=\quad$ standard deviation, in cubic inches 
bearing ferrosilicon produced higher wear rates compared to strontiumferrosilicon.

The volume-to-squeal (VTS in in ${ }^{3}$ ) column in Table VII contains two numbers, the volume of metal removed to drill squeal and the standard deviation. An analysis of variance (ANOVA) was conducted to determine the statistical confidence in conclusions that might be drawn from the data. The tool speed definitely influenced tool life, as is well known from shop experience.

The inoculating alloy was also found to be statistically significant at a $99 \%$ confidence level at a speed of $98 \mathrm{sfm}(0.50 \mathrm{~m} / \mathrm{s})$. This is the only speed below the tool wear transition point where data on all materials could be obtained. It is unfortunate that the available G8-U2-1 material was consumed in the higher speed drill experiments, and an insufficient amount remained for tool life determinations at speeds of 85 to $98 \mathrm{sfm}(0.43$ to $0.50 \mathrm{~m} / \mathrm{s})$.

\section{Microstructural and Physical Property Analysis}

All gray iron plate microstructures consisted principally of Type " $A$ " graphite in a fully pearlitic matrix. Only trace amounts of ferrite were found, and no eutectic carbides were found in any samples.

Several other properties of the gray iron plates are summarized in Table VII including the Brinell hardness, pearlite hardness, tensile and compression properties, microcarbides content, cell count, cell diameter, iron density, ultrasonic velocity and ultrasonic attenuation.

The Brinell hardness, as determined by making 45 measurements on the plate, was in the range of 220-225 BHN for the castings poured in no-bake molds and about 210 for the iron poured in the green sand mold and about 200 in G10-C-1, also poured in green sand molds.

The pearlite hardness was about 265 to 275 DPN in the castings poured in no-bake molds and 252 DPN in the G8 green sand casting and 300 in G10-C-1. The microcarbide content was in the range of $9.0 \%$ to 9.75\% in the castings made in no-bake molds, $11.1 \%$ in the green sand casting and $11.0 \%$ in $\mathrm{G} 10-\mathrm{C}-1$.

The eutectic cell count was higher, ranging from 188 to 250 cells per square centimeter in the irons inoculated with the strontiumbearing ferrosilicon, and highest in the iron poured in the green sand molds. The higher cell count in the iron poured in the green sand mold may be a result of a higher cooling rate during solidification. The cell size was also smallest in the castings poured in the green sand mold with an average diameter of $0.056 \mathrm{~cm}(0.022 \mathrm{in})$. The cell diameter was slightly larger in the strontium inoculated iron poured in the nobake mold and largest in the irons inoculated with the foundry grade and cerium-bearing ferrosilicon materials. The cell count (229 


\begin{tabular}{|c|c|c|c|c|c|c|}
\hline & 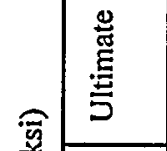 & $\stackrel{\stackrel{9}{9}}{=}$ & $\mid$ & 离 & \begin{tabular}{|l} 
İ \\
İ
\end{tabular} & \begin{tabular}{|c}
$\hat{\rho}$ \\
$\stackrel{\rho}{m}$
\end{tabular} \\
\hline & 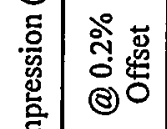 & i̊ & 祭 & 管 & 昌 & ì \\
\hline & 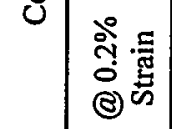 & 品 & 管 & $\frac{a}{m}$ & $\frac{n}{m}$ & స్ల \\
\hline & 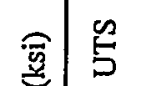 & $\mid \begin{array}{l}0 \\
\infty \\
\infty\end{array}$ & $\bar{q}$ & $\tilde{q}$ & $\underset{\infty}{\infty}$ & $\mid \begin{array}{l}\mathcal{H} \\
\mathcal{Z}\end{array}$ \\
\hline & \begin{tabular}{l|l}
$\frac{\pi}{5}$ \\
\multirow{2}{*}{}
\end{tabular} & ○्户 & ت్ర & 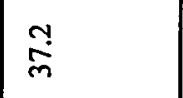 & $\stackrel{m}{m}$ & 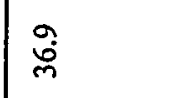 \\
\hline 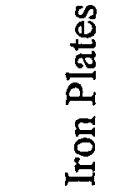 & 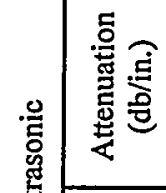 & $\approx$ & $\stackrel{\infty}{\circ}$ & 80 & $\stackrel{\infty}{\sim}$ & $\overrightarrow{0}$ \\
\hline 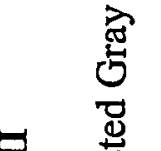 & 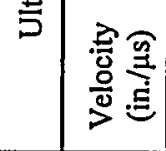 & $\stackrel{0}{\stackrel{\Phi}{0}}$ & $\stackrel{\infty}{0}$ & $\stackrel{\mathscr{\infty}}{\circ}$ & $\frac{\infty}{0}$ & $\frac{9}{9}$ \\
\hline 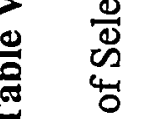 & 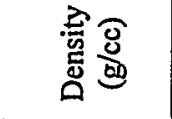 & ָั & ત્ત્ & ํํำ & त్ ָָ & 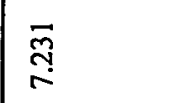 \\
\hline $\begin{array}{l}\text { E. } \\
\text { 总 } \\
\text { : }\end{array}$ & 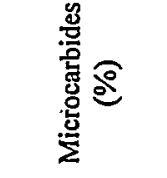 & 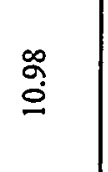 & $\stackrel{n}{a}$ & $\Xi$ & $\stackrel{m}{a}$ & $\therefore$ \\
\hline 管 & 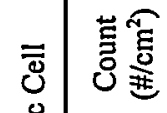 & స్ & $\stackrel{\infty}{\stackrel{\infty}{-1}}$ & $\bar{\Phi}$ & $\stackrel{\infty}{\Xi}$ & $\stackrel{\circ}{9}$ \\
\hline & 离离 & 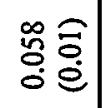 & 영 & 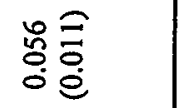 & $\begin{array}{l}\text { 옹 } \\
\text { : } \\
0\end{array}$ & 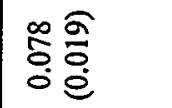 \\
\hline & z̆ & $\bar{D} \mathbb{d}$ & $\stackrel{d}{\varrho}$ & శ్ స్త్ర & 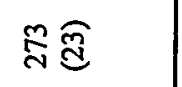 & $\stackrel{\circ}{\mathcal{G}}$ \\
\hline & 鿬 & $\bar{\sigma} \tilde{\hat{n}}$ & สิ & 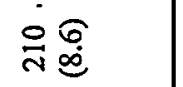 & $\widetilde{\widetilde{d}} \widehat{\widetilde{\sigma}}$ & $\approx \underset{\sigma}{\mathscr{\theta}}$ \\
\hline & 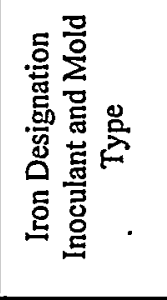 & 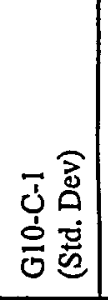 & 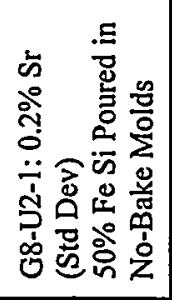 & 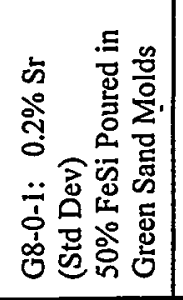 & 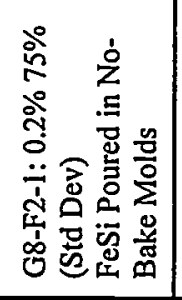 & 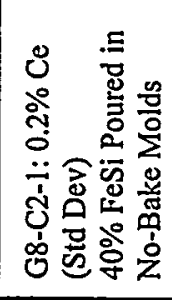 \\
\hline
\end{tabular}


cells $/ \mathrm{cm}^{2}, 1477$ cells $\left./ \mathrm{in}^{2}\right)$ and cell size $(0.058 \mathrm{~cm}, 0.023$ in.) of Gl0-C-1 lies between the results obtained with the irons inoculated with the strontium-bearing ferrosilicon and poured in green sand and no-bake molds.

The average eutectic cell sizes measured were statistically different at a 99\% confidence level as determined by a t-test. This difference in eutectic cell sizes indicates that there were differences in inoculant effectiveness.

The ultrasonic velocity through the experimental gray irons ranged from 0.185 to $0.190 \mathrm{in} / \mu \mathrm{s}(4700$ to $4825 \mathrm{~m} / \mathrm{s})$ and is highest in the castings inoculated with $0.2 \%$ addition of cerium-bearing $75 \%$ ferrosilicon. The ultrasonic attenuation ranged from 6.1 to $9.2 \mathrm{db} /$ in (240 to $360 \mathrm{db} / \mathrm{m})$, and was highest in G10-C-1.

Mean and standard deviation values for the Brinell hardness, matrix hardness (VHN), cell count, holes to squeal at $98 \mathrm{sfm}$ $(0.50 \mathrm{~m} / \mathrm{s})$, and holes drilled to produce 0.0065 inches $(0.17 \mathrm{~mm})$ average flank wear are illustrated in Figures 6 and 7 .

Machinability results obtained on these irons are compared with those from other foundries producing irons having a range of strengths and are illustrated in Figure 8. The irons toward the bottom of the figure represent a series of low alloy irons produced to have a strength ranging from about 32 to $48 \mathrm{ksi}(220$ to $335 \mathrm{MPa})$. The irons just discussed have strengths in the range of 38 to $43 \mathrm{ksi}$ (264 to $299 \mathrm{MPa}$ ). It is evident that irons $\mathrm{GIOC}$ and $\mathrm{G} 8-\mathrm{U} 2$ have about 5 times the machinability at the same strength as the irons $A$ and $B$ located at the bottom of the graph.

Based on the observation that irons at the same strength can exhibit drastically different machinability behaviors, a statistically designed experimental matrix was undertaken to see if certain elements might maintain strength but produce a more machinable iron. The experimental matrix is illustrated in Table IV.

The variables in this matrix were tin, molybdenum, copper, and nickel concentrations and section thickness. Some data was available that indicated that excess copper degraded machinability, and one objective of these experiments was to determine if nickel could be substituted for copper to maintain the strength but improve machinability. Each composition was cast as both one-inch $(25 \mathrm{~mm})$ and two-inch $(50 \mathrm{~mm})$ thick plates.

The iron designations, composition of each iron, type of mold, inoculant addition, pouring temperature and shake-out time are presented in Table V. Casting groups G8-5 and G8-2 had higher nickel and lower copper concentrations and groups G8-5 and G8-6 contained higher molybdenum concentrations. The remaining elemental concentrations were held essentially constant. 


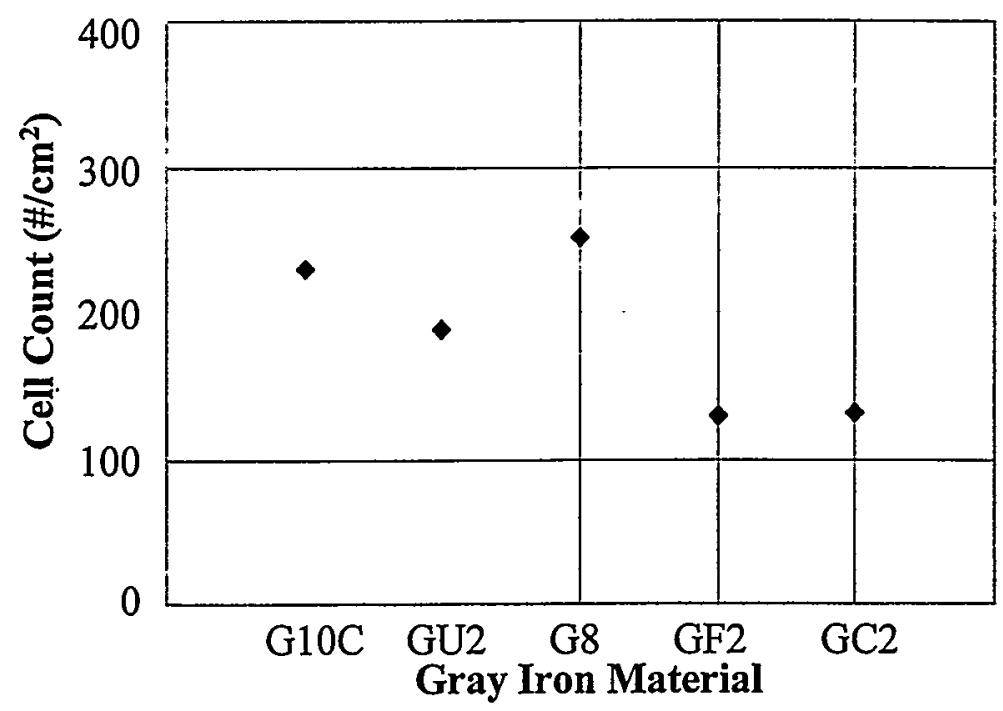

$(6 \mathrm{~A})$

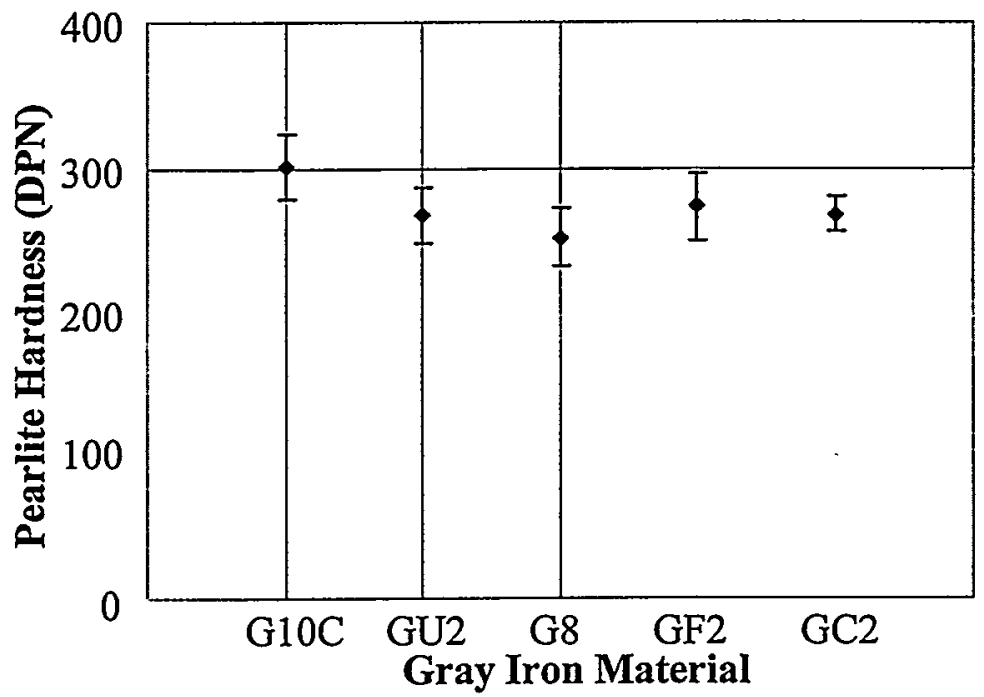

(6B)

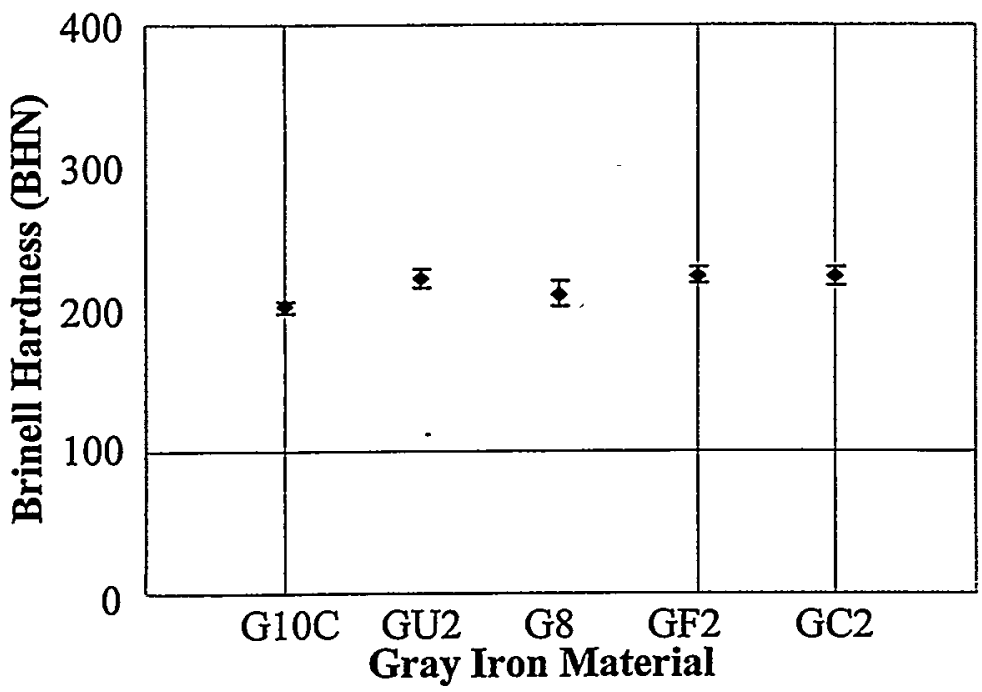

$(6 \mathrm{C})$

Figure 6. Some physical properties of the selected gray irons. (A) Cell count. (B) Matrix hardness. (C) Brinell hardness. 


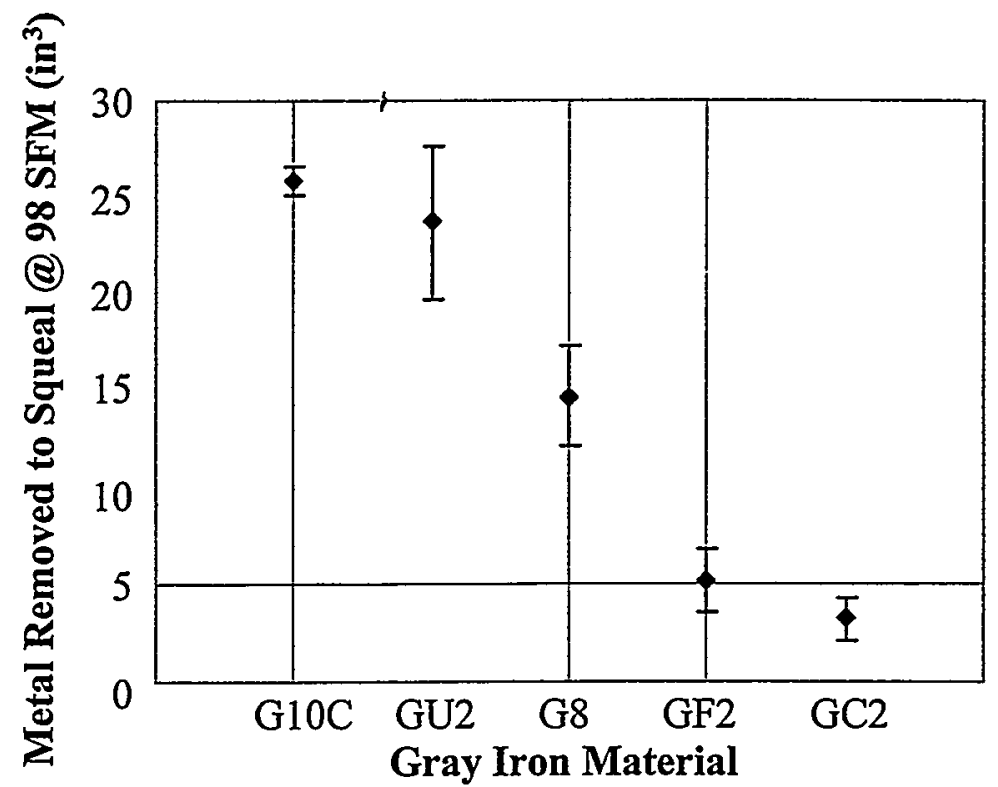

(7A)

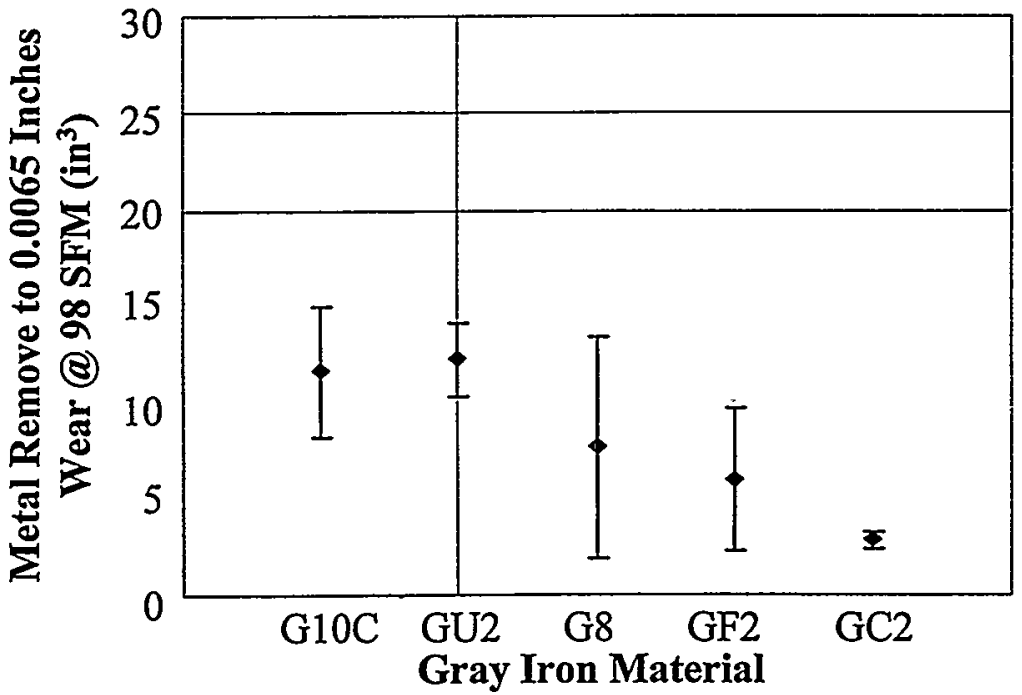

(7B)

Figure 7. Machinability of the selected gray irons at a drill surface speed of 98 SFM. (A) Metal volume removed to squeal at 98 SFM. (B) Metal volume removed to produce 0.0065 inches flank wear at 98 SFM. 


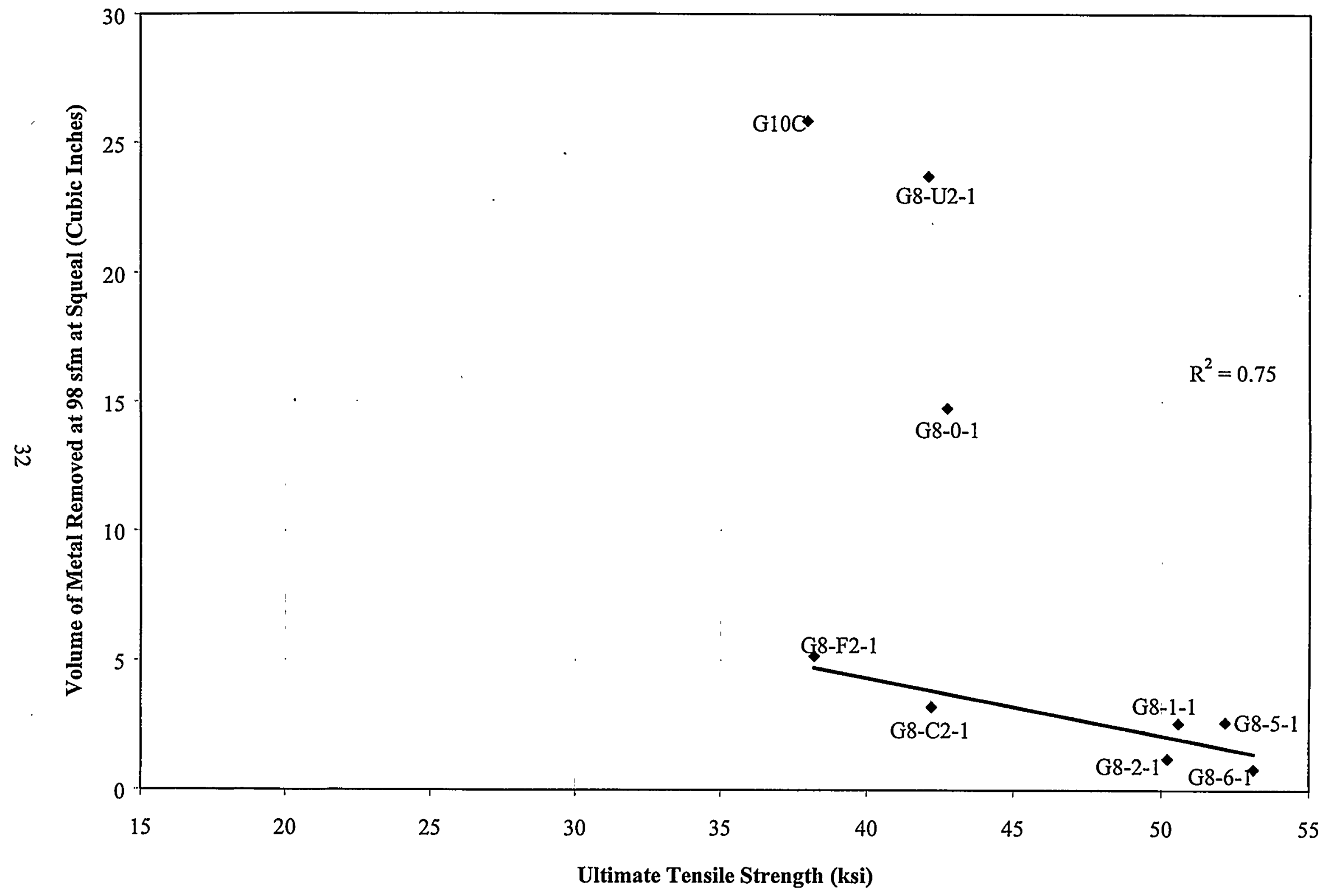

Figure 8. Correlation between Tool Life at 98 SFM and Tensile Strength - One Inch Thick Plates 
All castings were inoculated with $0.2 \%$ of $\mathrm{Sr}$ bearing $50 \%$ ferrosilicon, poured in green sand molds at a temperature of $2525 \mathrm{~F}$ (1385C) and left in the mold for just over two hours. The castings were below the eutectoid temperature at shake-out.

The volume of metal removed in the one-inch (25mm) and two-inch (50mm) thick plate castings is illustrated in Figure 9 and 10 as a function of drill speed.

The hardness, tensile yield strength, ultimate strength, compression strength, density and tool life data obtained on the oneinch $(25 \mathrm{~mm})$ thick plates are presented in Table VIII, and similar data on the two-inch $(50 \mathrm{~mm})$ plates are presented in Table IX.

A statistical analysis of the data is presented in Table $\mathrm{X}$. The copper concentration, thickness, tin concentration, copper and thickness interactions, and copper and tin interactions all had significant effects on machinability at a confidence level of $99 \%$ or higher.

The volume of metal that could be removed by drilling increased from approximately $2 \mathrm{in}^{3}\left(33 \mathrm{~cm}^{3}\right)$ at the higher copper concentration to $3.5 \mathrm{in}^{3}\left(57.4 \mathrm{~cm}^{3}\right)$ when about $0.25 \% \mathrm{Cu}$ was replaced by $0.25 \% \mathrm{Ni}$. The substitution of nickel for copper maintained the strength while improving the machinability.

The volume of metal that could be removed before drill failure also increased with section thickness. About $2 \mathrm{in}^{3}\left(33 \mathrm{~cm}^{3}\right)$ of metal could be removed from a one-inch $(25 \mathrm{~mm})$ thick casting compared to $3.5 \mathrm{in}^{3}$ $\left(57.4 \mathrm{~cm}^{3}\right)$ in a 2 inch $(50 \mathrm{~mm})$ thick casting. The difference in metal removal could be a result of a higher micro-carbide concentration in the one-inch $(25 \mathrm{~mm})$ thick casting, or it could be the higher work hardened surface per unit volume of metal removed from the one-inch $(25 \mathrm{~mm})$ thick casting.

Thickness was the only variable that had a highly statistically significant effect on strength, as shown by the analysis of variance in Table XI.

\section{Analysis of Commercial Gray Iron Castings}

Several companies have submitted "acceptable" and "hard-to-machine" commercial castings including disc hubs, diesel block cylinder bores, and diesel heads. The most frequent cause of poor machinability has been excessive microcarbides in the castings. These results have been described in detail in an earlier publication. (13)

In each case, the equilibrium microcarbide contents were calculated assuming fully pearlitic microstructures. The equilibrium microcarbide content was then analytically determined. Thermocalc (14) 


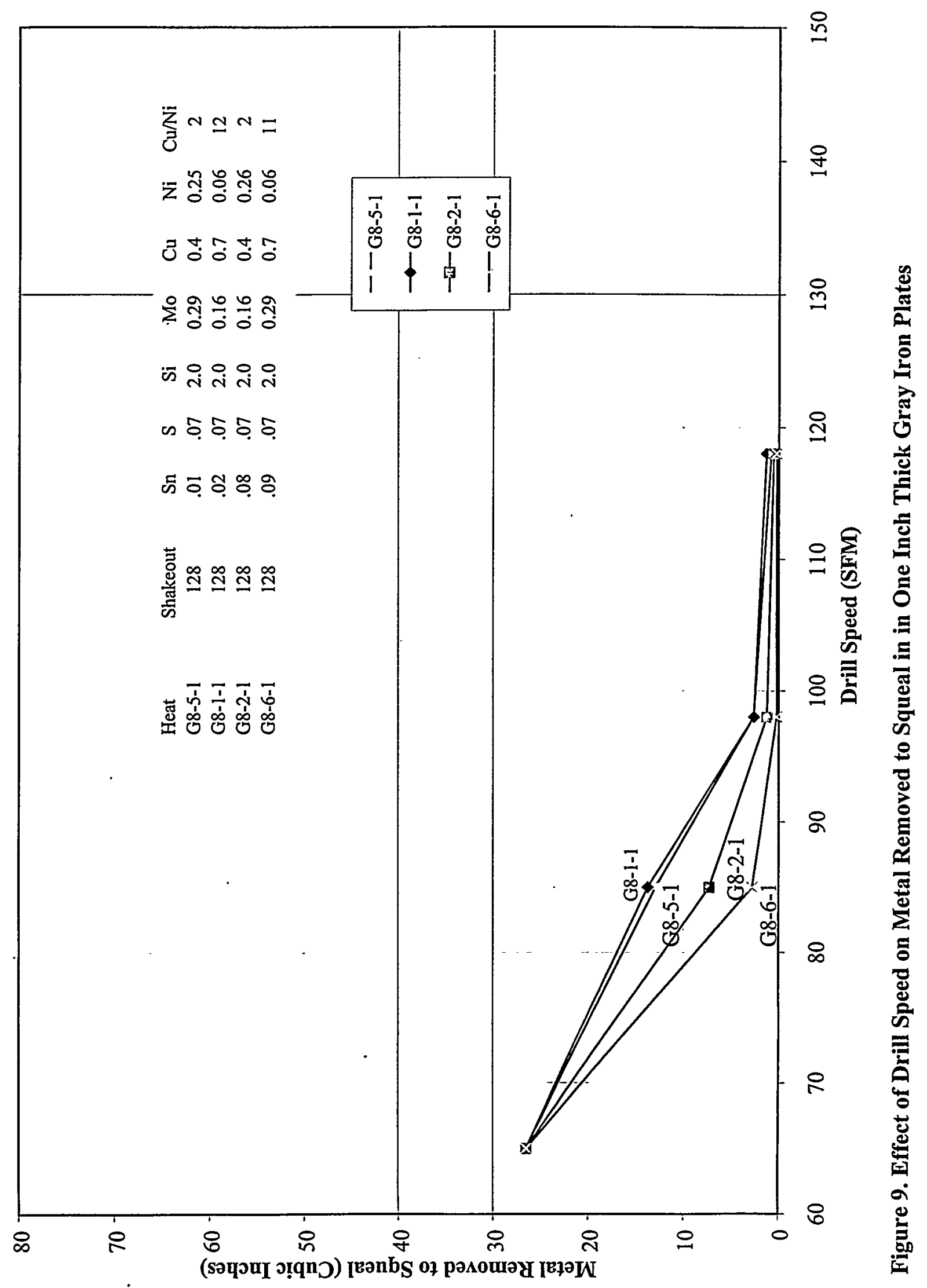




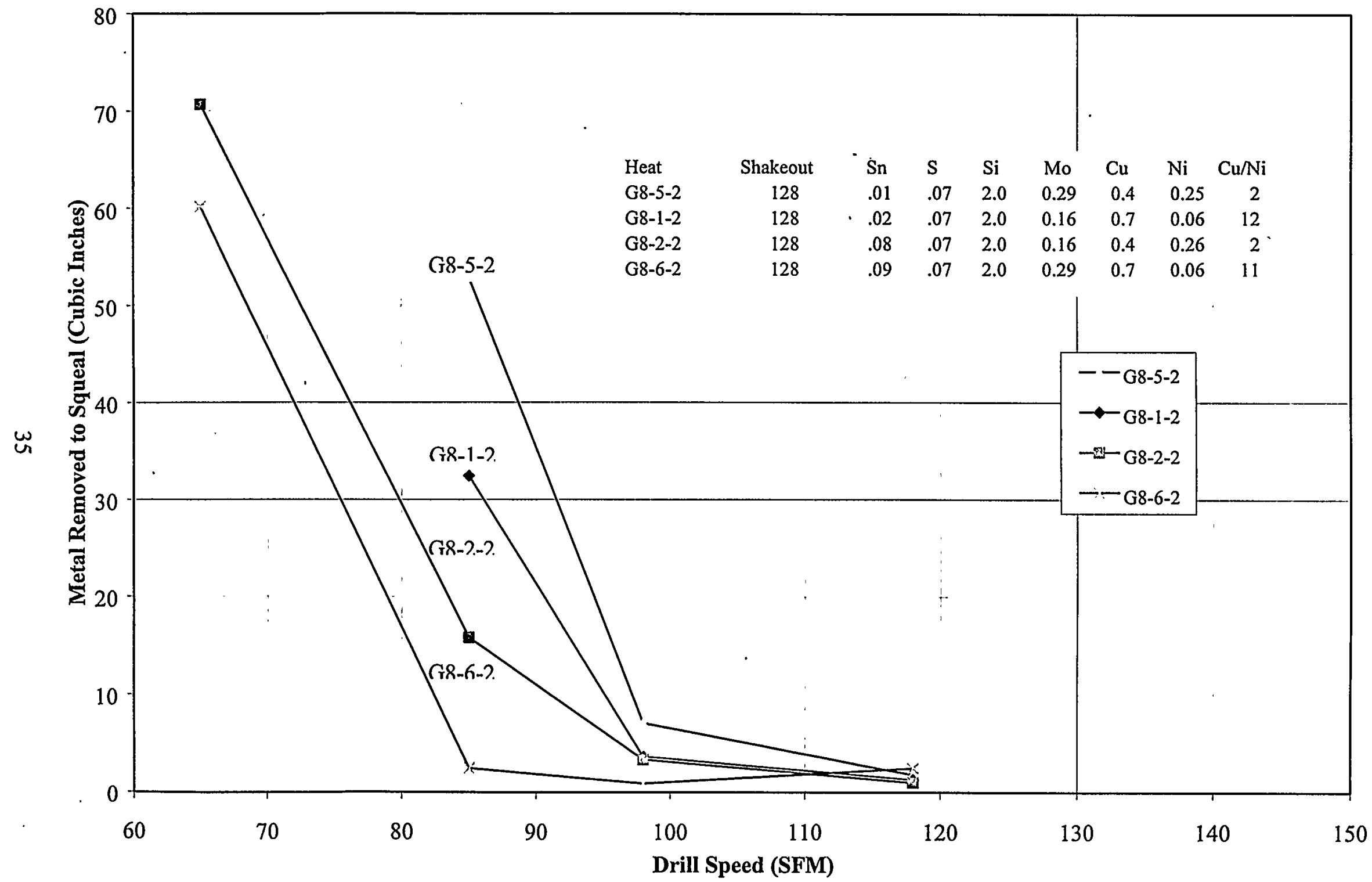

Figure 10. Effect of Drill Speed on Metal Removed to Squeal in in Two Inches Thick Gray Iron Plates 


\section{Table VIII}

Physical Properties of One Inch Thick Gray Iron Plates (50-54 ksi Ult.)

$\begin{array}{lllll}\text { Iron Designation } & \text { G8-5-1 } & \text { G8-1-1 } & \text { G8-2-1 } & \text { G8-6-1 } \\ \text { BHN (mean) } & 232 & 227 & 237 & 252 \\ \text { Std. Dev. } & 2.8 & 13.1 & 17.2 & 16.3 \\ \text { Tensile Yield(ksi) } & 45.58 & 46.24 & 45.31 & 48.49 \\ \text { Ultimate(ksi) } & 52.13 & 50.57 & 50.12 & 53.12 \\ \text { Compression } & & & & \\ \text { stress at 0.2 Strain(ksi) } & 34.00 & 46.00 & 33.10 & 38.00 \\ \text { stress at 0.2 Offset(ksi) } & 63.00 & 63.40 & 59.40 & 71.00 \\ \text { Ultimate(ksi) } & 150.60 & 246.80 ? & 139.40 & 160.00 \\ & & & & \\ \text { Density(g/cc) } & 7.239 & 7.248 & 7.260 & 7.269 \\ & & & & \\ \text { Tool life at } 98 \mathrm{sfm} & 71 & 70 & 33 & 22 \\ \text { Metal removed }\left(\mathrm{in}^{3}\right) & 2.61 & 2.58 & 1.21 & 0.81\end{array}$




\section{Table IX}

Physical Properties of Two Inch Thick Gray Iron Plates (43-45 ksi Ult.)

\begin{tabular}{|c|c|c|c|c|}
\hline Iron Designation & G8-5-2 & G8-1-2 & G8-2-2 & G8-6-2 \\
\hline $\mathrm{BHN}$ (mean) & 207 & 215 & 216 & 236 \\
\hline Std. Dev. & 5.3 & 3.8 . & 2.3 & 4.3 \\
\hline Tensile Yield(ksi) & 39.82 & 42.95 & 43.01 & 41.71 \\
\hline Ultimate(ksi) & 44.75 & 44.38 & 44.75 & 43.67 \\
\hline $\begin{array}{l}\text { Compression } \\
\text { stress at } 0.2 \text { Strain(ksi) }\end{array}$ & 31.40 & 31.00 & 33.40 & 34.00 \\
\hline stress at 0.2 Offset(ksi) & 54.40 & 54.00 & 56.00 & 62.00 \\
\hline Ultimate(ksi) & 117.40 & 121.60 & 118.00 & 126.00 \\
\hline Density $(g / c c)$ & 7.236 & 7.244 & 7.261 & 7.271 \\
\hline Tool life at $98 \mathrm{sfm}$ & 72 & 37 & 34 & 9 \\
\hline Metal removed $\left(\mathrm{in}^{3}\right)$ & 7.07 & 3.63 & 3.34 & 0.88 \\
\hline
\end{tabular}




\section{Table X}

Statistical Analysis of Copper, Nickel, Tin and Section Thickness on Machinability

Source $\quad$ Sum of Squares Df Mean Square F-Ratio P-Value

MAIN EFFECTS

$\begin{array}{llllll}\text { A:Cu Concentration } & 11.07004 & 1 & 11.0704 & 20.25 & 0.0003 \\ \text { B:Thickness } & 17.8537 & 1 & 17.8537 & 32.65 & 0.0000 \\ \text { C:Sn Concentration } & 41.6593 & 1 & 41.6593 & 76.19 & 0.0000\end{array}$

INTERACTIONS

$\begin{array}{llllll}\mathrm{AB} & 10.5073 & 1 & 10.5073 & 19.22 & 0.0004 \\ \mathrm{AC} & 0.1734 & 1 & 0.1734 & 0.32 & 0.5807 \\ \mathrm{BC} & 4.50667 & 1 & 4.50667 & & \end{array}$

$\begin{array}{llll}\text { RESIDUAL } & 9.29528 & 17 & 0.546781\end{array}$

\begin{tabular}{lll}
\hline TOTAL & 95.0661 & 23
\end{tabular}

All F-ratios are based on the residual mean square error. 


\section{Table XI}

Statistical Analysis of Copper and Nickel Effects on Ultimate Strength

Source Sum of Squares Df Mean Square F-Ratio P-Value

MAIN EFFECTS

$\begin{array}{llllll}\text { A:Cu Concentration } & 0.844 & 1 & 0.844 & 0.30 & 0.59 \\ \text { B:Thickness } & 364.26 & 1 & 364.26 & 128.47 & 0.000 \\ \text { C:Sn Concentration } & 0.454 & 1 & 0.454 & 0.16 & 0.69\end{array}$

INTERACTIONS

$\begin{array}{llllll}\mathrm{AB} & 1.45 & 1 & 1.45 & 0.51 & 0.48 \\ \mathrm{AC} & 4.59 & 1 & 4.59 & 1.62 & 0.22 \\ \mathrm{BC} & 2.73 & 1 & 2.73 & 0.96 & 0.34\end{array}$

$\begin{array}{llll}\text { RESDUAL } & 48.20 & 17 & 2.84\end{array}$

\begin{tabular}{lll}
\hline TOTAL & 422.54 & 23
\end{tabular}

All F-ratios are based on the residual mean square error. 
predicted an equilibrium carbide content of $8.54 \%$ to $8.64 \%$ in the hub irons, but the actual values were in the range of $13.23 \%$ to $13.68 \%$.

Diesel cylinder blocks with "acceptable" machinability had calculated equilibrium microcarbide contents of $7.89 \%$ and measured values of about 9.92\%. Cylinder blocks with "marginal" to "poor" machinability ratings had calculated equilibrium microcarbide contents of about $9.55 \%$, but the actual values ranged from $10.98 \%$ to $11.13 \%$. One block contained $12.6 \%$ microcarbides, the highest value observed in any of these irons.

Several cylinder heads were also submitted, and two regions of each casting were examined - a "thin" section about 1 inch (25mm) thick and a "thick" section about 4 inches (100mm) thick. Thermocalc predicted an equilibrium microcarbide weight percent based on the metal composition of about $9.5 \%$ in these castings. The microcarbide content in the thin sections considered to have acceptable machinability ranged from $9.47 \%$ to $9.62 \%$. The microcarbide content of the thin section castings considered to have poor machinability was in the range of $10.23 \%$ to $11.13 \%$.

The microcarbide content of the thick sections considered to have acceptable machinability ranged from $9.77 \%$ to $11.13 \%$. The microcarbide content of the thick sections of castings considered to be "hard-tomachine" ranged from $12.03 \%$ to $12.63 \%$

In all cases, the poorly machinable irons contained a higher concentration of microcarbides than the companion irons having acceptable machinability.

\section{Controlling Microcarbides}

It is a requirement that most gray irons contain about 9\% microcarbides by weight in order to produce a pearlitic matrix needed for strength and wear resistance. Some pearlite is also needed in ductile irons in order to improve matrix strength. However, excessive microcarbides create abrasive conditions for the tool without substantially contributing much to strength. The conditions that are known or suspected to increase the incidence of microcarbides are as follows:

1. high casting cooling rates between the eutectic and the eutectoid temperatures,

2. the presence of elements that retard carbon migration from austenite to eutectic graphite flakes, and

3. the presence of elements that stabilize carbide formation.

High cooling rates between the eutectic and the eutectoid temperaturés can be caused by wet sand, short shake-out times, cold sand, and the production of thin section castings. These conditions 
produce high heat removal rates from the metal and minimize the amount of time available for diffusion of carbon out of the austenite to the graphite flakes. Carbon dissolved in the austenite matrix at the time the eutectoid transformation takes place reacts with iron and other elements to form dispersed microcarbides.

Several elements retard carbon migration from austenite to the graphite flakes. These elements stabilize pearlite without reacting with carbon to form a stable carbide. These elements include copper, tin, arsenic, and antimony, and they appear to function by forming an atomic barrier that retards the movement of carbon atoms from the austenite to graphite flakes and nodules. (10)

Small amounts of these elements are quite helpful in producing pearlitic irons. However, excessive amounts retard carbon migration to such an extent that the austenite becomes supersaturated with carbon and then transforms to pearlite containing excessive amounts of microcarbide particles.

Some elements, including chromium, molybdenum, titanium, vanadium, and zirconium, form stable carbides by reactions with carbon as the iron cools. Chromium decreases the temperature difference between the upper and lower eutectic temperatures and promotes the formation of massive eutectic carbides. However, chromium also favors the formation of microcarbides by reacting with carbon between the eutectic and eutectoid temperatures.

Molybdenum has a minor effect on eutectic carbide formation, but mainly reacts with carbon in austenite to form a stable molybdenum carbide that is thought to degrade machinability. Titanium, vanadium, and zirconium also react with carbon to form carbides that are distributed throughout the matrix. Quantitative data on the individual effects of these elements does not exist.

\section{Gray Iron Machinability Indicators}

Compressive properties. Two techniques are being explored as quick response machinability indicators. The first consists of determining the compression properties, and the second is an ultrasonic measurement made on castings.

Much of the energy expended on the work piece during machining is associated with the compressive shear deformation that occurs ahead of the advancing cutter. Based on this fact, it was hypothesized that measurements of the compressive properties might provide a measure of machinability.

Right circular cylinders, one quarter inch (6.5mm) diameter by one half inch $(12.5 \mathrm{~mm})$ long, were removed from selected castings, strain gages applied, and compression properties measured by testing between parallel platens. Superimposed stress strain curves from a 
variety of irons are illustrated in Figure 11, and the tool life (number of holes drilled before tool failure at $124 \mathrm{sfm}(0.63 \mathrm{~m} / \mathrm{s})$ ) is given at the end of each pair of compression curve. There was a consistent decrease in machinability as the compressive strength increased.

Compression test results are informative because they reflect the shear strength of the iron. However, such tests may not reflect the presence of disparate abrasive inclusions such as oxides, nitrides, or other particles that might accelerate tool wear. Other procedures, such as microscopic or ultrasonic procedures, will be required to reflect these conditions.

Ultrasonic Indicators. Ultrasonic evaluation procedures offer some promise of providing machinability information because disparate particles cause wave scattering and attenuation. Ultrasonic response is obtained from the bulk of the testing material, not only from a section of it. Most ultrasonic tests are conducted to determine the presence of internal discontinuities such as voids or large inclusions or to determine the material modulus. Ultrasonic measures of graphite nodularity depend on obtaining a velocity value that reflects graphite shape effects on modulus.

Ultrasonic velocity and ultrasonic attenuation also provide information that correlates with machinability. Ultrasonic velocity can be used to estimate the elastic modulus of the iron, provided the material density and Poisson's ratio are known. The elastic modulus reflects the size, shape and amount of the graphite present. Graphite decreases the continuity of the matrix, adds compliance, and thus lowers the modulus of cast iron relative to pure iron. The pearlite to ferrite ratio also has important effects on modulus and hence on ultrasonic velocity, especially in the case of ductile iron. The chipforming process during machining is controlled by all the phases present in cast iron. The force exerted on the flank of the tool is a function of the modulus. This force, coupled with the coefficient of friction between the material and the tool, produces heat which raises the tool tip temperature. When this friction force is sufficiently high to raise the tool temperature to its softening point, the tool rapidly degrades. In general, higher modulus materials produce higher friction forces and, when coupled with materials containing abrasive constituents, tool wear is accelerated.

Ultrasonic attenuation is a result of scattering and absorption of the wave energy being transmitted through the material. (15) scattering occurs as the ultrasonic energy encounters interfaces within the material. These interfaces can be grain boundaries, flaws (holes, cracks, etc.), or, in the case of cast iron, graphite flakes and nodules. The magnitude of scattering is dependent on the size of the interface in relation to the ultrasonic wavelength. Research has shown that frequencies in the range of $2 \mathrm{MHZ}$ to $10 \mathrm{MHz}$ provide the wavelengths that are sensitive to typical graphite flake sizes. Absorption of ultrasonic energy is independent of interfaces and is 


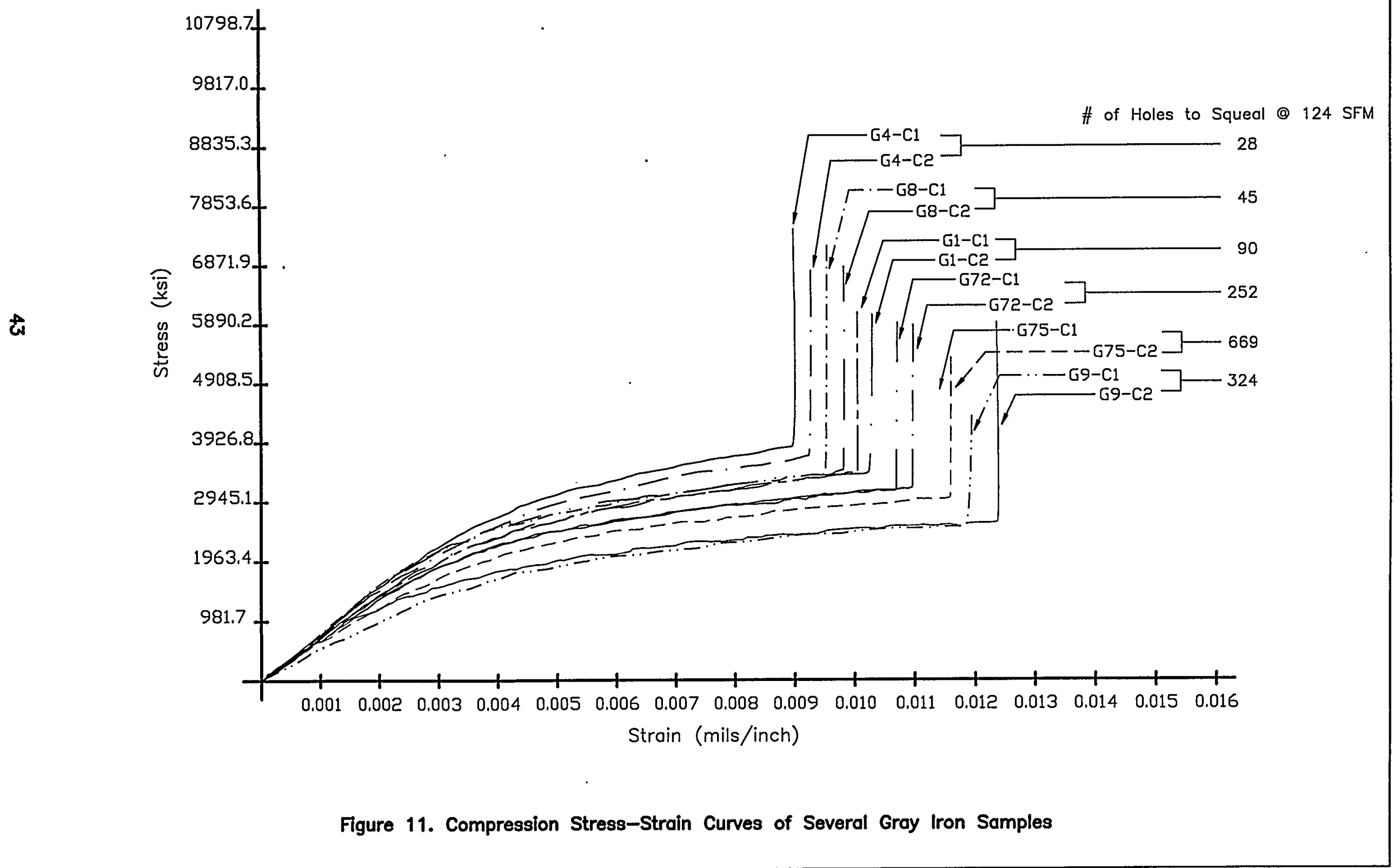


related to the atomic structure of the material. Pearlite to ferrite ratio will affect the energy absorption. This absorbed energy will be converted to heat.

A correlation between ultrasonic velocity and the metal volume that can be removed at a surface speed of $98 \mathrm{SFM}(0.50 \mathrm{~m} / \mathrm{s})$ to the squeal of the cutting tool through one and two-inch (25m and $50 \mathrm{~mm}$ ) thick plates poured from a variety gray irons is illustrated in Figure 12. Higher ultrasonic velocities were associated with a less amount of metal volume removed. Significantly higher amount of metal can be removed from Plates G8-5-2 than from G8-6-2 or G8-6-1. The power regression analysis was used and the $R^{2}$ is about 0.9 . The measurement error of the ultrasonic velocity is less than 0.001 in/us $(25.4 \mathrm{~m} / \mathrm{s})$. The two-inch thick (50mm) plates have relatively lower ultrasonic velocity than their one-inch $(25 \mathrm{~mm})$ thick comparator, which agrees with the difference in machinability. Cooling rates affects microstructure and machinability and can be indicated from ultrasonic velocity measurements.

In general, the plates with the lower amount of metal removed to squeal possess both higher elastic modulus values and higher ultimate compressive strengths. These are important since the stress state in the chip is primarily compressive. The graphite flake size largely determines both the elastic modulus and ultimate tensile strength, with smaller flake sizes producing higher strengths. Smaller flakes reduce the continuity of iron matrix less than larger flakes, and associated with the smaller flakes are higher modulus values that produce larger flank face friction forces. The higher compressive strengths associated with small flakes require a higher strain energy to form the chip and probably produce more heat during chip formation. It is also a general observation that cast irons with smaller flake sizes tend to have higher microcarbide content, which provide the abrasive particles for tool wear.

\section{Applications}

As the data base on process effects on machinability is developed, efforts have been made to test the data and concepts on problem commercial parts. One company had repeated complaints about poor machinability of a compressor piston. Samples of the piston were examined, and it was found that the castings varied in microcarbide content. It was hypothesized that there was some variability in the cooling cycle which caused variations in microcarbides, which in turn caused some variability in machinability. The machine shop could not find a "consistent" machining practice because of the variability in the castings supplied.

Adjustments were made in the process to achieve microcarbide consistency, and over two million parts have been machined without any customer complaints. This result was obtained because of the correlations developed between microstructural characteristics and machinability. 


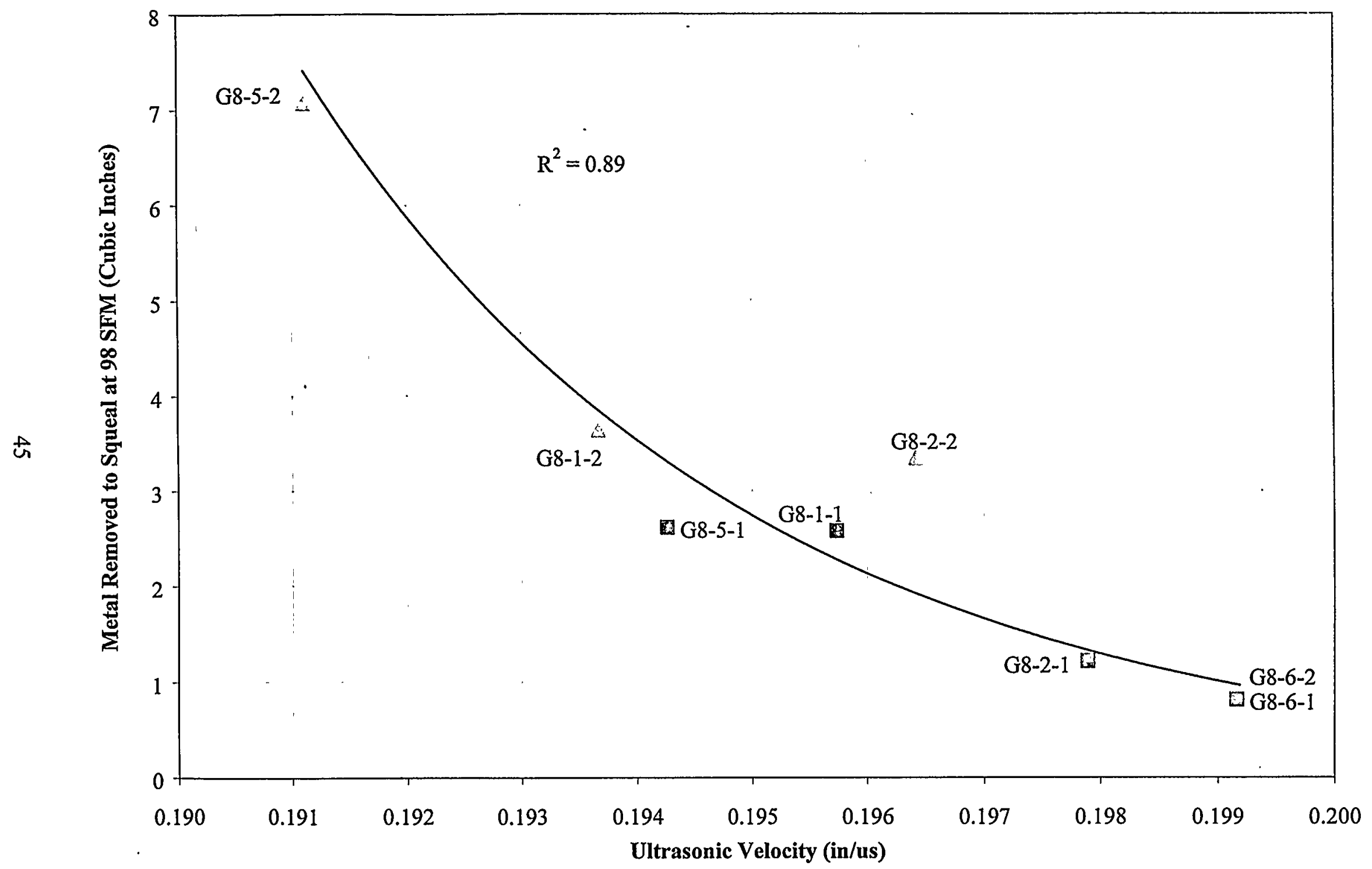

Figure 12. Correlation between Ultrasonic Velocity and Metal Removed to Squeal at 98 SFM in Gray Irons 
A second foundry had intermittent machining complaints usually in the winter months. An examination of the process led to the conclusion that the casting cooled too quickly when poured early on a cold day. Scheduling production of the critical casting later in the shift (after the system sand had warmed up) eliminated this customer complaint. The cold sand was causing excessively fast cooling and poor machinability.

\section{Machinability of Ductile Iron}

The purpose of experimental studies on ductile iron was to determine the effects of composition and microstructure on machinability. The primary variables were the copper and tin concentrations. The base iron contained approximately $0.08 \%$ copper and $0.005 \%$ tin. An addition of $0.35 \%$ copper was made to casting series D10-2, and an addition of approximately $0.1 \%$ tin was made to series D10-3. Both the tin and the copper concentration was raised in casting Series D10-4. The experimental matrix is presented in Table XII.

The actual concentrations of copper and tin, the amount of ferrite and mechanical properties in each iron are presented in Table XIII. The pearlite content was $18 \%$ in the base iron, and increased to $56 \%$ with an addition of $0.38 \%$ copper. The pearlite increased to $75 \%$ with an addition of $0.099 \%$ tin and increased to essentially $100 \%$ in the iron containing $0.5 \% \mathrm{Cu}$ and $0.1 \% \mathrm{Sn}$.

The volume of metal removed from each of these irons is illustrated as a function of tool speed and is illustrated in Figure 13. Approximately 700 holes $\left(25 \mathrm{in}^{3}, 425 \mathrm{~cm}^{3}\right)$ could be drilled in the base iron containing $18 \%$ pearlite at speeds anywhere in the experimental range. An increase in the copper concentration to $0.38 \%$ increased the pearlite content to $56 \%$. This did not adversely affect the machinability at a low machining speed off $65 \mathrm{sfm}(0.33 \mathrm{~m} / \mathrm{s})$, but the machinability was dramatically decreased at speeds of 85 and 118 sfm $(0.43$ to $0.60 \mathrm{~m} / \mathrm{s})$. The number of holes that could be drilled before tool failure decreased from approximately 700 at the 65 sfm $(0.33 \mathrm{~m} / \mathrm{s})$ to less than 100 at the higher speeds.

Machinability was further reduced by the addition of $0.1 \%$ tin which increased the pearlite content to 75\%. Approximately 7 cubic inches $\left(115 \mathrm{~cm}^{3}\right)$ could be removed before tool failure at a speed of 65 $\operatorname{sfm}(0.33 \mathrm{~m} / \mathrm{s})$ but no more than $1.8 \mathrm{in}^{3}\left(30 \mathrm{~cm}^{3}\right)$ could be removed before drill failure at speeds of 85 and $118 \mathrm{sfm}(0.43$ to $0.60 \mathrm{~m} / \mathrm{s})$. When the iron was made fully pearlitic with additions of $0.5 \%$ copper and $0.1 \%$ tin, less than 1 in $^{3}\left(16 \mathrm{~cm}^{3}\right)$ could be removed before tool failure at any speed within the experimental range.

The volume of metal that could be removed at a speed of $85 \mathrm{sfm}$ $(0.43 \mathrm{~m} / \mathrm{s})$ is illustrated in Figure 14, and the volume progressively decreased with pearlite content. A correlation between the volume of 


\section{Table XII}

D10 Base Iron Nominal Composition

$\begin{array}{ll}\mathrm{C} & 3.60-3.90 \% \\ \mathrm{Si} & 1.40-1.60 \% \text { Base } \\ \mathrm{Mn} & 0.30 \mathrm{Max} \\ \mathrm{Cu} & 0.08-0.15+0.35 \text { to Get Pearlitic } \\ \text { Residuals: } & 0.05 \mathrm{Ni} \\ & 0.035 \mathrm{Cr} \\ & 0.035 \mathrm{Mo}\end{array}$

Structure: $\quad 75 \%$ Ferrite

$25 \%$ Pearlite

\section{EXPERIMENTAL MATRIX}

$\begin{array}{lll}\text { Heat No } & \underline{\mathrm{Sb} / \mathrm{Cu}} & \underline{\mathrm{Sn}} \\ (1) & - & - \\ (2) & + & - \\ (3) & - & + \\ (4) & + & + \\ & & \\ & \text { Base }+ & \text { Base }+ \\ & 0.01 \mathrm{Sb} \text { or } & 0.075 \mathrm{Sn} \\ & 0.35 \mathrm{Cu} & \end{array}$




\section{Table XIII}

Processing, Composition, and Properties of One Inch Thick Ductile Iron Plates (71-96 ksi Ult.)

\begin{tabular}{|c|c|c|c|c|}
\hline Iron Designation & D10-1 & D10-2 & D10-3 & D10-4 \\
\hline Furnace & - & 一 & - & - \\
\hline \multicolumn{5}{|l|}{ Composition } \\
\hline $\mathrm{C}$ & 3.60 & 3.65 & 3.58 & 3.57 \\
\hline $\mathrm{Si}$ & 2.73 & 2.70 & 2.71 . & 3.00 \\
\hline $\mathrm{Mn}$ & 0.19 & 0.20 & 0.20 & 0.20 \\
\hline $\mathrm{Mg}$ & 0.039 & 0.038 & 0.032 & 0.040 \\
\hline $\mathrm{Cr}$ & 0.04 & 0.03 & 0.03 & 0.03 \\
\hline Mo & - & - & - & - \\
\hline $\mathrm{Ni}$ & 0.04 & 0.02 & 0.02 & 0.02 \\
\hline $\mathrm{Cu}$ & $0.08 \mathrm{Lo}$ & $0.38 \mathrm{Hi}$ & $0.06 \mathrm{Lo}$ & $0.51 \mathrm{Hi}$ \\
\hline $\mathrm{Ti}$ & 0.010 & 0.007 & 0.007 & 0.007 \\
\hline $\mathrm{Sn}$ & $0.005 \mathrm{Lo}$ & $0.005 \mathrm{Lo}$ & $0.099 \mathrm{Hi}$ & $0.097 \mathrm{Hi}$ \\
\hline $\mathrm{Sb}$ & $<0.003$ & $<0.003$ & $<0.003$ & $<0.003$ \\
\hline Treatment & FloTret & FloTret & FloTret & FloTret \\
\hline \multicolumn{5}{|l|}{ Amount (\%) } \\
\hline Mold & GS & GS & GS & GS \\
\hline Pour Temp & $\sim 2600$ & $\sim 2600$ & $\sim 2600$ & $\sim 2600$ \\
\hline Shakeout & Black & Black & Black & Black \\
\hline BHN (mean) & 161.0 & 222.0 & 270.2 & 294.6 \\
\hline Std. Dev. & 6 & 8.0 & 4.3 & 4.9 \\
\hline Tensile Yield(ksi) & 47.56 & 57.79 & 67.75 & 75.00 \\
\hline Ultimate(ksi) & 71.25 & 82.96 & 95.54 & 88.29 \\
\hline Density(g/cc) & 7.071 & 7.075 & 7.136 & 7.144 \\
\hline Tool life at $85 \mathrm{sfm}$ & 720 & 87 & 60 & 5 \\
\hline Metal removed $\left(\mathrm{in}^{3}\right)$ & 26.51 & 3.20 & 2.21 & 0.18 \\
\hline Pearlite Volume Frac & 18. & 56. & 75. & 99. \\
\hline
\end{tabular}




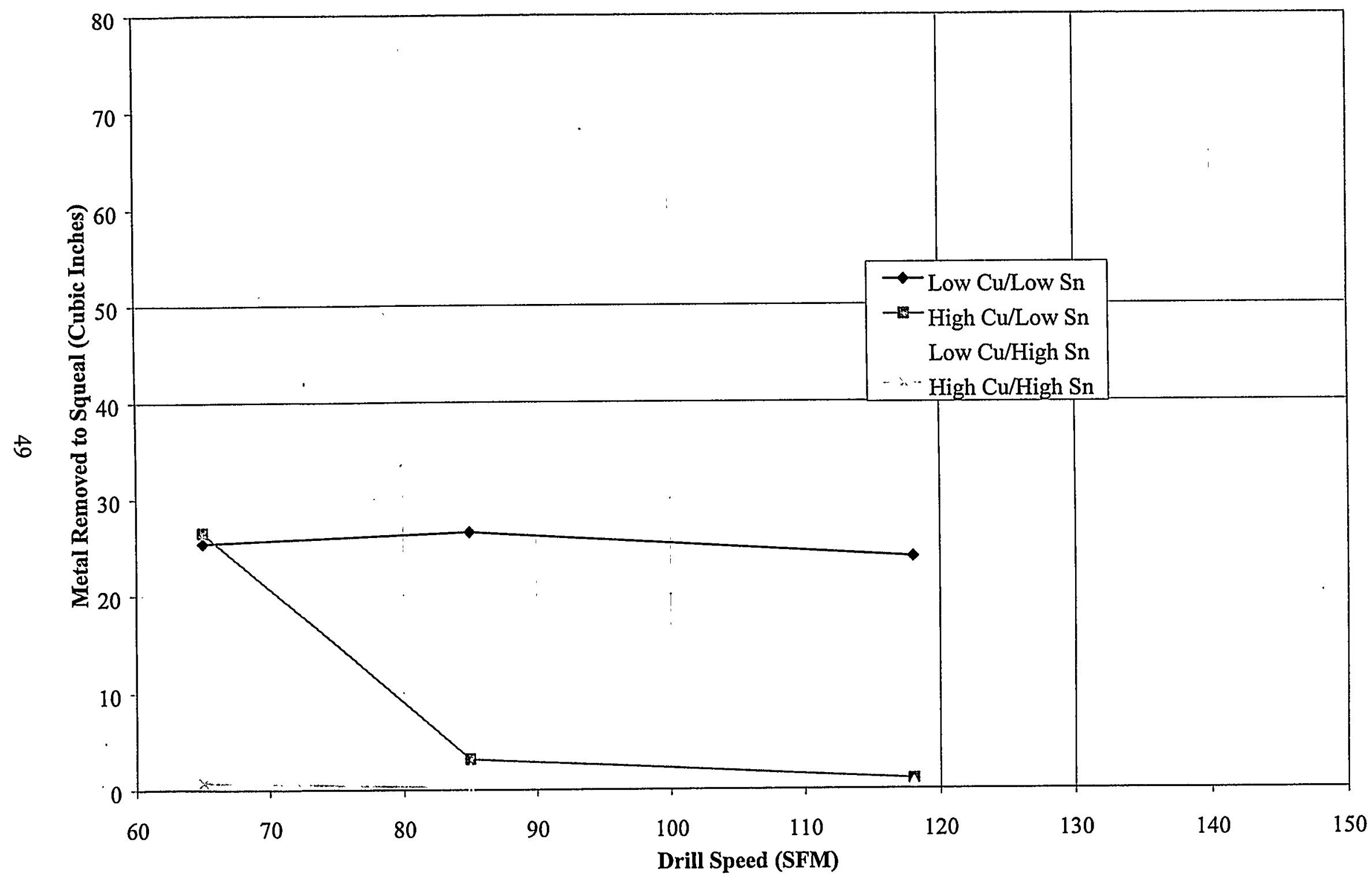

Figure 13. Effect of Matrix Structure on Metal Volume Removed to Drill Squeal at Various Drill Speeds 


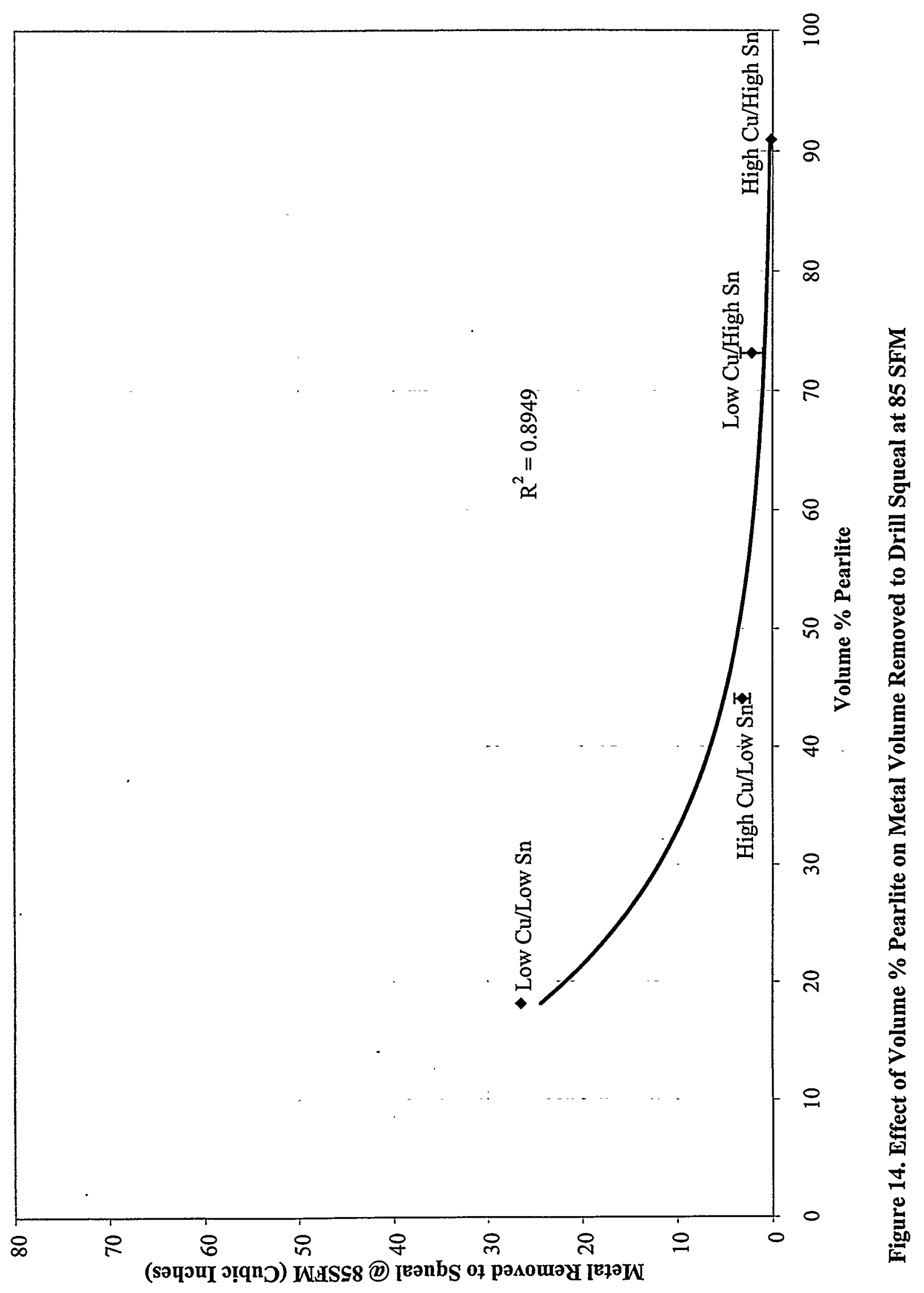


metal removed before tool failure and the hardness is illustrated in Figure 15. The rate of tool wear increased and the volume of metal removed before tool failure progressively decreased as the pearlite content and hardness of the iron increased.

Data relating the yield strength of the iron to the volume of metal that could be removed before tool failure is illustrated in Figure 16. The metal volume removed before tool failure progressively decreased as the yield strength increased in a manner similar to that produced by the pearlite content and hardness.

The yield strengths of these irons as a function of ferrite content are illustrated in Figure 17. A linear relationship was found between the yield strength and the ferrite content. The equation for the relationship is given below, and the correlation coefficient was 0.99 .

$$
\text { Yield Strength }(\mathrm{ksi})=-0.3768 \times \text { \%Ferrite }+74.664
$$

An analysis of variance was made on the data to determine the probability that the factors being studied were significant and to determine the contribution of each variable to the variation in tool life. The results are presented in Table XIV.

The copper and tin concentration and interactions between the copper and tin were statistically significant at a very high confidence level. The copper addition accounted for $35 \%$ and the tin addition accounted for $41 \%$ of the variation in drill life. Interactions between the copper and tin accounted for the remainder of the variation in tool life, which was $21 \%$

A similar analysis of variance was made to determine the effects of the minor additions on the volume fraction of pearlite in the microstructure. The results are presented in Table XV.

Increasing the copper concentration from $0.072 \%$ to $0.45 \%$ was highly significant and contributed to $17 \%$ of the variation in pearlite content. Increasing the tin concentration from $0.005 \%$ to $0.09 \%$ was also significant and contributed $82 \%$ to the variation in pearlite content. Interactions between the copper and tin were also statistically significant but only contributed approximately $1 \%$ to the variation in the pearlite content.

A similar analysis of variance was made to relate the copper and tin additions to the yield strength, and the results are presented in Table XVI. The copper and tin had significant effects with the copper addition explaining $18 \%$ of the variation and the tin addition explaining $82 \%$ of the variation. 


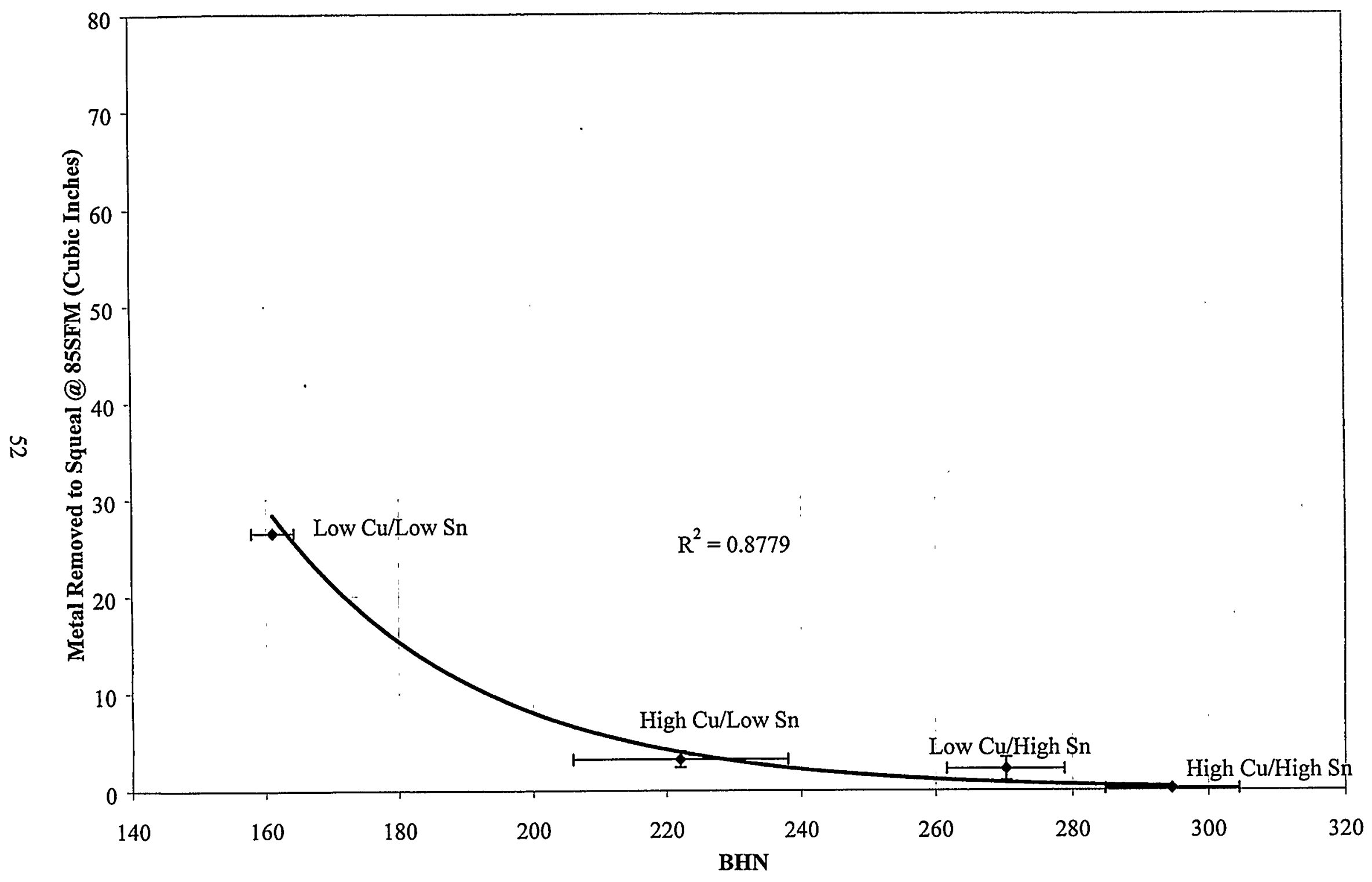

Figure 15. Effect of BHN on Metal Volume Removed to Drill Squeal at 85 SFM 


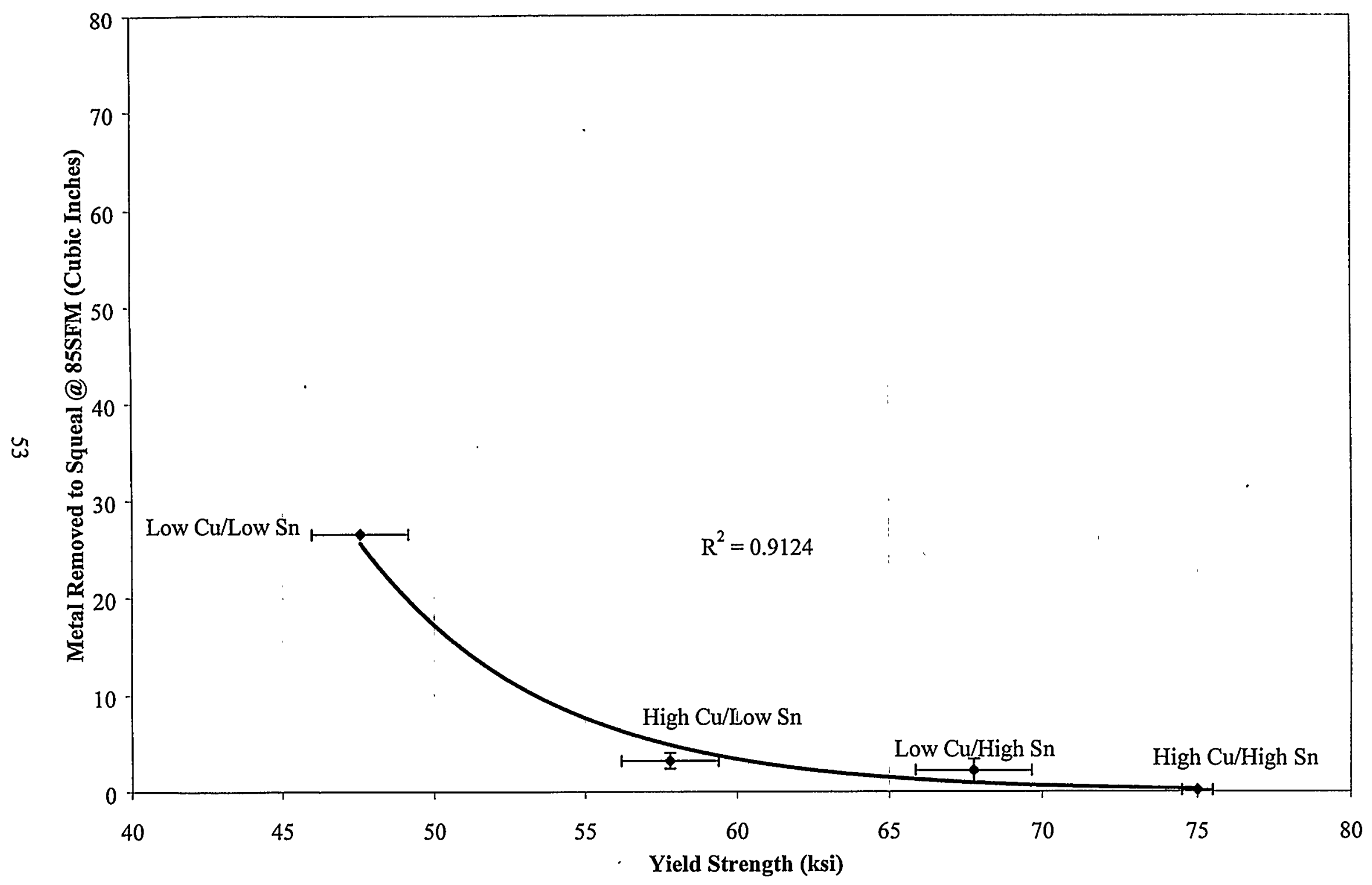

Figure 16. Effect of Yield Strength on Metal Volume Removed to Drill Squeal at 85 SFM 


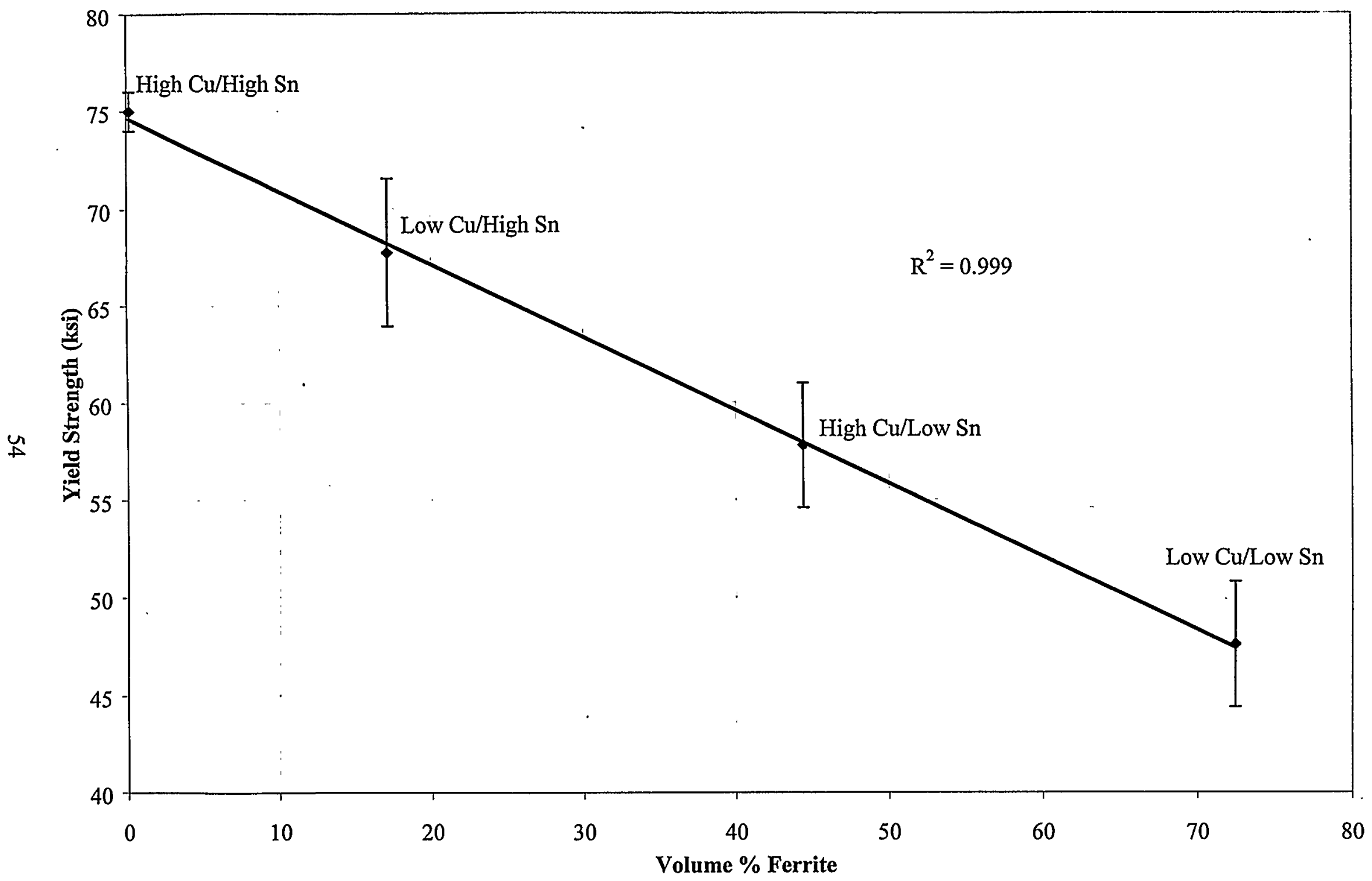

Figure 17. Effect of Volume \% Ferrite on Yield Strength. 


\section{Table XIV}

ANOVA Statistics for The Effect of Pearlite Stabilizers on Metal Removed to Squeal @ 85 SFM

\begin{tabular}{|c|c|c|c|c|}
\hline & Source & Sum of Squares & P-Value & $\begin{array}{c}\text { Contribution to Total } \\
\text { Variation }\end{array}$ \\
\hline Main Effects & $\begin{array}{c}\text { Cu Concentration } \\
(0.07-0.45)\end{array}$ & 355008 & 0.0000 & $35 \%$ \\
\cline { 2 - 5 } & $\begin{array}{c}\text { Sn Concentration } \\
(0.005-0.097)\end{array}$ & 413665 & 0.0000 & $41 \%$ \\
\hline Interactions & $\mathrm{Cu}$ and Sn & 249985 & 0.000 & $21 \%$ \\
\hline & Residual & 745.333 & & \\
\hline & Total (Corrected) & $1.0194 \mathrm{E} 6$ & & \\
\hline
\end{tabular}




\section{Table XV}

ANOVA Statistics for The Effect of Pearlite Stabilizers on Percent Pearlite Content in Matrix

\begin{tabular}{|c|c|c|c|c|}
\hline & Source & Sum of Squares & P-Value & $\begin{array}{c}\text { Contribution to Total } \\
\text { Variation }\end{array}$ \\
\hline Main Effects & $\begin{array}{c}\text { Cu Concentration } \\
(0.07-0.45)\end{array}$ & 1516 & 0.0000 & $17 \%$ \\
\cline { 2 - 5 } & $\begin{array}{c}\text { Sn Concentration } \\
(0.005-0.097)\end{array}$ & 7429 & 0.0000 & $82 \%$ \\
\hline Interactions & $\mathrm{Cu}$ and Sn & 91.3 & 0.000 & $1 \%$ \\
\hline & Residual & 0 & & \\
\hline & Total (Corrected) & 9037 & & \\
\hline
\end{tabular}


Table XVI

ANOVA Statistics for The Effect of Pearlite Stabilizers on Yield Strength

\begin{tabular}{|c|c|c|c|c|}
\hline & Source & Sum of Squares & P-Value & $\begin{array}{c}\text { Contribution to Total } \\
\text { Variation }\end{array}$ \\
\hline Main Effects & $\begin{array}{c}\text { Cu Concentration } \\
(0.07-0.45)\end{array}$ & .229 & 0.0000 & $18 \%$ \\
\cline { 2 - 5 } & $\begin{array}{c}\text { Sn Concentration } \\
(0.005-0.097)\end{array}$ & 1049 & 0.0000 & $82 \%$ \\
\hline & $\checkmark$ & 606 & & \\
\hline & Residual & 1285 & & \\
\hline
\end{tabular}




\section{Conclusions}

The pearlite content of ductile iron has been found to have a strong effect on machinability. The data obtained in this study indicates that tool life progressively decreases as the pearlite content, hardness, and strength of ductile irons increase. Additions of tin and copper increased the pearlite content and reduced machinability. This effect is undoubtedly caused by the effect of these elements on the combined carbon and micro-carbide content of the irons. By inference, higher concentrations of elements such as manganese, chromium, and other pearlite forming elements can be expected to increase the micro-carbide content and reduce the machinability of ductile iron. 


\section{SUMMARY AND CONCLUSIONS}

\section{Grav Iron}

This study was conducted to evaluate the effects of inoculation and processing on the machinability of gray iron. This report focuses on the results obtained in a series of irons having a nearly constant strength of about $40 \mathrm{ksi}(278 \mathrm{MPa})$. The irons were inoculated with (1) $0.2 \%$ additions of strontium-bearing of $50 \%$ ferrosilicon, (2) $0.2 \%$ additions of $75 \%$ ferrosilicon containing calcium and aluminum, (3) $0.2 \%$ additions of $40 \%$ ferrosilicon containing cerium.

1. Statistically significant differences were found in machinability at the 99\% confidence level. G10-C-1, inoculated with $0.2 \%$ FeSi and poured at $2550 \mathrm{~F}(1400 \mathrm{C})$, exhibited the lowest density and best tool Iife of all the irons in this study. The strontiumbearing inoculants produced the best tool life of all the irons poured in Foundry G8. The strontium-bearing irons exhibited slightly lower densities, which suggests this inoculant to be a better graphitizer.

2. The iron designated G8-U2-1 inoculated with strontium-bearing ferrosilicon and poured no-bake molds produced a slightly lower drill wear rate than the iron poured in the green sand molds (G8-0-1), perhaps because of slightly lower cooling rates in no-bake molds.

3. The number of holes that could be drilled in G8-F2-1 inoculated with 75\% FeSi and G8-C2-1 inoculated with cerium-bearing $40 \%$ ferrosilicon was about half that attainable with the strontiumbearing ferrosilicon at speeds below $100 \mathrm{sfm}(0.51 \mathrm{~m} / \mathrm{s})$ or $\mathrm{G} 10-\mathrm{C}-1$.

4. All tool life curves obtained on the Class 40 gray iron converged at a drill speed of about $110 \mathrm{sfm}(0.56 \mathrm{~m} / \mathrm{s})$.

5. The eutectic cell counts were higher in the irons inoculated with the strontium-bearing ferrosilicon, and higher in the iron poured in green sand molds than in the irons poured in no-bake molds.

6. The irons with higher cell counts produced lower tool wear rates and the best tool life.

7. A lower tool life was found in the irons having a higher ultrasonic velocity and lower attenuation. The velocity and attenuation effects are probably related to the graphite size and shape. Additional work will be required to define the best graphite shape and methods for consistently achieving the preferred shape.

8. In general, inoculating additions containing larger amounts of highly'oxidizable elements resulted in shorter tool lives. It is possible that additions containing larger amounts of calcium, aluminum, barium, cerium and similar oxidizable elements reacted with air and moisture during pouring to produce abrasive oxides distributed throughout the metal. 
9. Substantial differences were found in the machinability a gray irons having the same strength. The differences were sometimes as much as $500 \%$. The most machinable irons were those with a high cell count and few carbo-nitride inclusions.

10. The substitution of some copper with nickel resulted in an iron with better machinability and no sacrifice in strength.

11. Additions of tin and copper can be added to stabilize pearlite in iron, but excessive additions (above those required to produce the desired pearlite content) degrade the machinability.

12. Compression properties appear to provide a good indication of the "base" machinability of gray irons. Compression test results may not reflect the presence of disparate abrasive inclusions such as oxides, nitrides, or other particles that accelerate tool wear.

13. Irons containing higher concentrations of microcarbides caused higher tool wear rates in laboratory machining experiments. Commercial castings reported by machine shops to be harder to machine were examined and were found to contain higher concentrations of microcarbides.

14. Ultrasonic velocity offers promise as a quality control tool for assessing machinability. It appears to reflect the graphite volume, size and shape which largely controls the chip forming process during machining.

15. Processing changes have been implemented in commercial foundries using the results of the program and significant improvements in machinability obtained.

Ductile Iron

The purpose of experimental studies on ductile iron was to develop quantitative data on the effects of matrix microstructure on machinability. The microstructure was controlled by using additions of copper and tin.

1. The lowest tool wear rates were obtained with matrices containing more ferrite. Tools could be used to remove $25 \mathrm{in}^{3}\left(410 \mathrm{~cm}^{3}\right)$ of iron at speeds in the range of 65 to $118 \mathrm{sfm}(0.33$ to $0.60 \mathrm{~m} / \mathrm{s})$ in the iron containing less than $20 \%$ pearlite.

2. The volume of metal that could be removed prior to drill failure progressively decreased as ferrite was replaced by pearlite.

3. There was an asymptotic decrease in the volume of metal that could be removed by drilling with increasing yield strength of the metal. 
4. A linear relationship was found between the yield strength and the ferrite content.

5. A statistical analysis was conducted to determine the variance in tool life associated with copper and tin concentration variations. Both were highly significant. The addition of $0.38 \% \mathrm{Cu}$ accounted for $35 \%$ of the tool life variability, and the addition of $0.10 \% \mathrm{Sn}$ accounted for $41 \%$ of the variation. Interactions between the copper and tin accounted for the remainder of the variation in tool life, which was $21 \%$.

6. A similar analysis of variance was made to relate the copper and tin additions to the yield strength. The copper and tin had significant effects with the $0.38 \% \mathrm{Cu}$ addition explaining $18 \%$ of the variation and the $0.10 \% \mathrm{Sn}$ addition explaining $82 \%$ of the variation. 


\section{ACKNOWLEDGMENTS}

We are deeply grateful for the companies who interrupted hectic production schedules to produce the experimental castings used in this study. A special word of thanks goes to the American Foundrymen's Society for their financial support of the project.

Several students, staff, and faculty made significant contributions to the project. Dr. Evangelos Eleftheriou and Jeff Sprague developed the procedures used to perform the drill wear tests and make the wear measurements. Much of the experimental work and some refinements in technique were made by $\mathrm{Mr}$. George Lewis, first as an undergraduate research assistant and then as a Research Engineer.

We are also indebted to the US Department of Energy for support provided under agreement DE-FC07-97ID13555. Our hope is that this information on inoculation effects will be of assistance to companies throughout the United States in advancing the technology needed to produce machinable thin wall iron castings.

Submitted by:<smiles>CCCCCCC(C)CC</smiles><smiles>C1CC2CCCC2C1</smiles>
Robin Griffin, Ph.D. Research Engineer

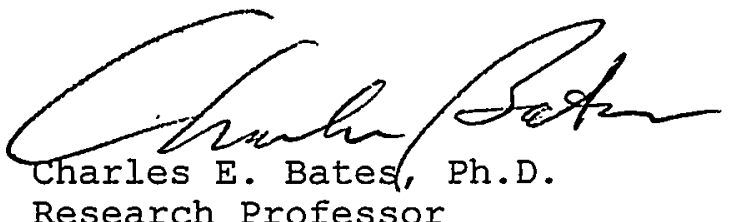

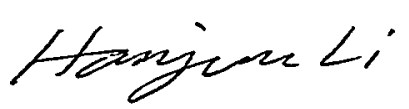

Hanjun Li

Research Assistant

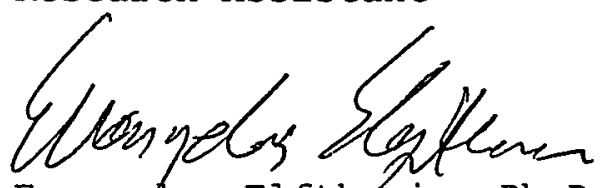
Evangelos Elftheriou Ph.D. Re fezrch Professor 


\section{REFERENCES}

1. Pispanen, V. "Tekmillen Tikakanslehti." 27, 1937, pp. 315-322.

2. Ernst, Hans. "Physics of Metal Cutting." Machining of Metals, American Society for Metals, Cleveland, Ohio, 1938, 177 pp., P. $1-34$.

3. Merchant, M. E. "Mechanics of the Metal Cutting Process. I. Orthogonal Cutting and a Type 2 Chip. " Journal of Applied Physics, vol. 16, No. 5, 1945, pp. 267-275.

4. Shaw, M. C. Metal Cutting Principles, Clareton Press . Oxford, New York, 1986.

5. Harris, G.G. Bibliography of Machinability Tests, Battelle Memorial Institute, Columbus, Ohio, 1944. 12 pages.

6. Schlesinger, George. "How to Measure Machinability in the Shop." American Machinist, Vol. 90, November 21, 1946, pp. 117-128.

7. ISO 3685 "Tool-life Testing With Single-point Turning Tools."

8. ANSI B94-34-1971 "Life Tests of Single -Point Tools Made for Materials Other than Sindered Carbides."

9. ASTM E 618 - 81 "Evaluating Machining Performance of Ferrous Metals Using an Automatic Screw/Bar Machine," 1984.

10. Bates, C.E. "Effects of Inoculation on the Machinability of Gray and Ductile Cast Iron." An American Foundrymen's Society Special Report, July 1998.

11. Kovacs, B.V. "Pearlite Stabilization in Cast Irons." American Foundrymen's Society Transactions 1981, p. 79-96.

12. Griffin, R.D.; Scarber, P.; Janowski, G.M.; Bates, C.E. Quantitative Characterization of Graphite in Gray Iron, Transactions of the American Foundrymen's Society V 104 Paper 96-129 P 977-983, 1996

13. Bates, C.E. Clean Iron Production And machining Technology, AFS-University of Alabama-Birmingham, (UAB) Summary Report, $P$ 1-17, Mar 5, 1996

14. Thermocalc. Division of Computational Thermodynamics of the Department of Materials Science \& Engineering, Royal Institute of Technology: S100-44 Stockholm, Sweden

15. Schmerr, L.W., JR. "Fundamentals of Ultrasonic Nondestructive Evaluation - A Modeling Approach", Plenum Press, New York and Iondon, 1998. 
USE OF THIS REPORT AND INFORMATION

CONTAINED THEREIN

\section{Publicity}

This report and the information contained therein is the property of the individual or organization named on the face hereof and may be freely distributed in its present form. However, the University of Alabama at Birmingham (UAB) hereby reminds sponsor that no advertising or publicity matter, having or containing any reference to the University of Alabama at Birmingham, shall be made use of by anyone, unless and until such matter shall have first been submitted to and received the approval in writing of UAB. (UAB does not usually approve any type of endorsement advertising.)

\section{Limitation of Liability}

The faculty and staff of UAB associated with this project have used their professional experience and best professional efforts in performing this work. However, UAB does not represent, warrant or guarantee that its research results, or product produced therefrom, are merchantable or satisfactory for any particular purpose, and there are no warranties, express or implied, to such effect. Acceptance, reliance on, or use of such results shall be at the sole risk of sponsor. In connection with this work, UAB shall in no event be responsible or liable in contract or in tort for any special, indirect, incidental or consequential damages, such as, but not limited to, loss of product, profits or revenues, damage or loss from operation or nonoperation of plant, or claims of customers of Sponsor.

TO: DEPARTMENT OF ENERGY

IDAHO OPERATIONS

850 Energy Drive

Idaho Falis, Idaho

Date: October 27, 2000

UAB Account No. 527976

E-File: \\Mmeceb\ceb_e 2 Publications $\backslash 8$ Machinability $\backslash 9,00$ Annual\9,00Text.wpd 